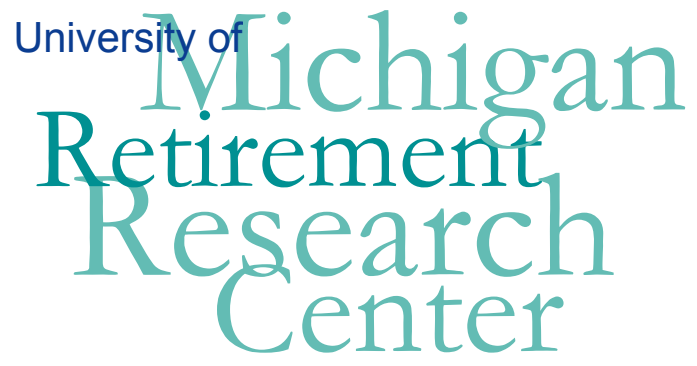

Working Paper WP 2004-079

The Impact of the 1996 SSI Childhood Disability Reforms: Evidence from Matched SIPP-SSA Data Lynn A. Karoly and Paul S. Davies

\begin{tabular}{|l|l|}
\hline $\mathrm{M}$ & $\mathrm{R}$ \\
\hline $\mathrm{R}$ & $\mathrm{C}$ \\
\hline
\end{tabular}$\quad$ Project \#: UM03-C1 


\title{
The Impact of the 1996 SSI Childhood Disability Reforms: Evidence from Matched SIPP-SSA Data
}

\author{
Lynn A. Karoly \\ RAND
}

Paul S. Davies

Social Security Administration

\author{
June 2004 \\ Michigan Retirement Research Center \\ University of Michigan \\ P.O. Box 1248 \\ Ann Arbor, MI 48104
}

\section{Acknowledgements}

This work was supported by a grant from the Social Security Administration through the Michigan Retirement Research Center (Grant \# 10-P96362-5). The opinions and conclusions are solely those of the authors and should not be considered as representing the opinions or policy of the Social Security Administration or any agency of the Federal Government.

\section{Regents of the University of Michigan}

David A. Brandon, Ann Arbor; Laurence B. Deitch, Bingham Farms; Olivia P. Maynard, Goodrich; Rebecca McGowan, Ann Arbor; Andrea Fischer Newman, Ann Arbor; Andrew C. Richner, Grosse Pointe Park; S. Martin Taylor, Gross Pointe Farms; Katherine E. White, Ann Arbor; Mary Sue Coleman, ex officio 


\title{
The Impact of the 1996 SSI Childhood Disability Reforms: Evidence from Matched SIPP-SSA Data
}

\author{
Lynn A. Karoly \\ Paul S. Davies
}

\begin{abstract}
The Personal Responsibility and Work Opportunity Reconciliation Act of 1996 changed the definition of disability used to determine eligibility for disabled children under the Supplemental Security Income (SSI) program and made other changes in the program. The law required the redetermination of eligibility status for children potentially affected by the new definition of disability. As a result, an estimated 100,000 children were expected to lose SSI benefits. The goal of this paper is to understand the impact of benefit loss on affected children and their families. The analysis draws on data from the 1992, 1993 and 1996 panels of the Survey of Income and Program Participation matched with Social Security Administration records on SSI program participation. The data are used to analyze the impact of the loss of SSI income as a result of the 1996 legislation on family labor supply, welfare program participation, and income and poverty. Compared with families that lost SSI benefits due to normal attrition from the program, the excess benefit loss due to the 1996 childhood disability reforms is associated with lower levels of family labor supply, higher levels of participation in AFDC/TANF and food stamps, and lower levels of family income relative to poverty. For some outcomes, these effects - measured one month after benefit loss-persist for up to 12 months.
\end{abstract}

\section{Authors' Acknowledgement}

Support for this project was provided by the Social Security Administration through the Michigan Retirement Research Center. The authors thank Howard Iams, Jacob Klerman, Jeannette Rogowski, and Kalman Rupp for comments on an earlier draft. Randall Hirscher, Jill Gurvey, and Boichi San provided excellent programming support. Bob Schoeni graciously provided state-level data on the implementation of pre-TANF (Temporary Assistance to Needy Families) waivers and the post-1996 implementation of TANF, as well as state-level unemployment rates. The opinions expressed and conclusions drawn in this paper are the responsibility of the authors, and do not represent the official views of the Social Security Administration, other agencies, or RAND. 
The Personal Responsibility and Work Opportunity Reconciliation Act (PRWORA) of 1996 changed the definition of disability used to determine eligibility for disabled children under the Supplemental Security Income (SSI) program and made other changes to the program. The law required the redetermination of eligibility status for children potentially affected by the new definition of disability. In addition, the law required that all children reaching age 18 be redetermined for eligibility based on the adult disability criteria. As a result of PRWORA and the SSI childhood disability redetermination process, an estimated 100,000 children were expected to lose SSI benefits. In prior work, Karoly, Hirscher, and Rogowski (2000) have documented this is approximately the number of children under age 18 who lost SSI benefits after July 1997 as a result of the stricter eligibility standard. The goal of this paper is to understand the impact of benefit loss due to the 1996 reforms on affected children and their families.

The analysis draws on data from the 1992, 1993 and 1996 panels of the Survey of Income and Program Participation (SIPP) matched with Social Security Administration (SSA) administrative records on SSI program participation for children under age 18. The SIPP, a nationally representative longitudinal survey of U.S. families, is used to examine three key outcomes: family income and poverty status, employment status of the child's mother and father, and family participation in other social welfare programs. These outcomes are among the most relevant for understanding the impact of the SSI changes on child and family well-being and they can be readily measured in the SIPP data. The SSA administrative data provide more accurate information on monthly participation in the SSI program than the self-reported data in the SIPP.

The choice of these outcomes is also motivated by prior research. For example, previous studies suggest that termination of SSI benefits will lead to an increase in parental labor supply, although the magnitude of this effect is uncertain (see, e.g., Garrett and Glied, 1997; Kubik, 1997). The anticipated positive labor supply effect may be attenuated to the extent that former SSI recipients are eligible for other assistance programs (e.g., Temporary Assistance for Needy Families, TANF, or other safety net programs such as food stamps or general assistance) which themselves provide a disincentive for greater work effort. The severity of the child's disability may also present barriers to increased work effort, particularly in single parent families. The SIPP data can be used to examine the extent to which work effort increases as a result of the 1996 childhood disability reforms and families' transition to other social safety net programs. Changes in work effort and receipt of public assistance will affect total family income and the family's poverty status as well. Depending on the family's response in terms of additional employment income and use of government programs, family income (and hence poverty status) may improve or worsen. The net effect on family income and poverty status must be determined empirically.

The goal of the empirical analysis is to determine the impact of the loss of SSI income as a result of the 1996 PRWORA legislation on family labor supply, welfare program participation, and income and 
poverty. To accomplish this, we adopt a modeling strategy that is designed to control for other factors besides the legislative change that may affect outcomes for families with children. In particular, the empirical model considers the differences in outcomes for two groups of children: children who retain their SSI benefits over some interval of time and children who lose their SSI benefits over the same interval of time, either because of normal attrition from the SSI program or because of a policy change such as the 1996 welfare reform legislation. By using the experience of children who lost benefits in the period before the policy change as a comparison group, we can net out the effect of normal attrition and capture only the effect of the policy change. In essence, we are asking: How are the children who lost their benefits different from those who retained their benefits in the period after the policy change versus the period before the policy change? In addition, we go one step further and consider two types of children receiving SSI benefits in the PRWORA reform period: those who had disability diagnoses that were not affected by the stricter eligibility criteria contained in the 1996 legislation and those who had disability diagnoses that required a redetermination of their continued eligibility for SSI. The first group of children should not be affected by the 1996 PRWORA changes to the SSI childhood disability program. The second group, however, might be affected. Thus, we can use the first group - the unaffected group - as a comparison for the affected group.

The next section provides some relevant background on the SSI childhood disability program and the 1996 reforms. In the two sections that follow, we provide an overview of the analytical framework and the empirical approach we use to study the effects of the legislation on child and family outcomes. We then discuss the matched SIPP-SSA data and how they are used in the empirical analysis. The results are presented next, with both descriptive findings and regression-based analyses discussed in turn. Some sensitivity analyses are discussed as well. The final section offers concluding observations.

\section{BACKGROUND}

The SSI program, initiated in 1974 following the 1972 amendments to the Social Security Act, is one of several programs that form the social safety net for low-income individuals and families in the United States. ${ }^{1}$ The federally administered program provides assistance to low-income elderly, blind, and disabled individuals. ${ }^{2}$ In the remainder of this section, we provide some relevant background on the childhood disability component of the SSI program and briefly describe the reforms implemented with the 1996 PRWORA legislation.

\footnotetext{
${ }^{1}$ Other programs include Temporary Assistance for Needy Families (TANF) (formerly Aid to Families with Dependent Children (AFDC)), food stamps, and housing assistance programs.

2 See SSA (2003) for additional details on the SSI program.
} 


\section{The SSI Childhood Disability Program}

The SSI childhood disability component of the program provides benefits to low-income children under age 18 with disabilities (Aron, Loprest and Steuerle, 1997). Monthly cash SSI benefits are typically paid on the child's behalf to the child's parent or guardian (as the representative payee). Many states supplement the federal SSI payments. In addition, receipt of SSI immediately qualifies individuals for Medicaid benefits in most states. Eligibility for SSI requires meeting income and asset limits, as well as the criteria for disability.

The statutory definition of disability for adults under SSI requires an individual to be "unable to engage in any substantial gainful activity by reason of any medically determinable physical or mental impairment which can be expected to result in death or which has lasted or can be expected to last for a continuous period of not less than 12 months" (SSA, 1995). Until recently, the Social Security Act did not have a separate definition of disability for children. Instead, based on the Social Security Act, a child under age 18 was considered disabled if he or she had a "medically determinable physical or mental impairment of comparable severity" to a disabling impairment in an adult (SSA, 1995). Before 1990, children who were not working qualified for SSI only if their conditions met or medically equaled a condition in the Listing of Impairments established for determining disability in adults. Unlike adults who had the opportunity to show that they were disabled even if they did not have impairments that met or equaled a listing (through a determination of residual functional capacity), children who did not have a condition that met or equaled a listing were denied benefits.

The February 1990 Supreme Court decision Sullivan v. Zebley found that the failure to provide individual assessment of function in children, analogous to the residual functional capacity assessments in adults, violated the SSI statutes, as did the failure to provide adequate evaluation of children with unlisted impairments or combinations of impairments that did not fulfill all the criteria for any one listed impairment (Sullivan v. Zebley, 493 U.S. 521 (1990)). In response to Zebley, SSA issued new regulations in February 1991 which explicitly defined the comparable severity of an impairment in childhood as one that affects a "child's ability to grow, develop, or mature physically, mentally, or emotionally" and limits the child's "ability to function independently, appropriately, and effectively in an age-appropriate manner" (SSA, 1995). SSA further implemented this definition with a multi-step evaluation process intended to be analogous to the adult evaluation process. The process included steps that allowed for "an individualized functional assessment" (IFA), with assessment of functioning in multiple domains. ${ }^{3}$ In the same period, another important modification to the childhood program was the publication of expanded mental disorders listings for children in December of 1990.

\footnotetext{
${ }^{3}$ Depending on the child's age, the IFA included an assessment of as many as six of the following domains: cognitive, communicative, motor, social, personal/behavioral, task completion (concentration, persistence, and pace) and for infants, responsiveness to stimuli.
} 
Following the expansion of the childhood SSI disability criteria in 1990, the SSI childhood caseload began to grow rapidly. In December 1990, just over 300,000 children received SSI disability benefits. By December 1995, following a period of unprecedented growth in the SSI rolls, that figure had tripled to 917,000 children (SSA, 2003). As the childhood caseload rapidly increased, the composition changed dramatically as well. For example, between 1989 and 1994, the percentage of children receiving SSI whose primary diagnosis was mental retardation (MR) and other mental impairments increased from 48 percent to 61 percent (National Commission on Childhood Disability, 1995). By the time of the passage of PRWORA, more than two-thirds of SSI children were eligible because of mental impairment, and about one-quarter were eligible based on listings for psychotic or neurotic psychiatric disorders (SSA, 1997a).

The overall growth in the number of childhood SSI recipients has been attributed to several factors, including changes in the program rules in December 1990, the eligibility changes resulting from Zebley, increasing childhood poverty rates, and expanded SSI outreach activities required by statute (see Rupp and Stapleton, 1995). There were also concerns, including reports in the media, of families coaching their children to act up in school to invite a behavior problem diagnosis (e.g., attention deficit disorder), although studies by SSA, the Office of the Inspector General, and the General Accounting Office did not show any evidence of widespread coaching or other abuses (GAO, 1995a, 1995b). This concerncombined with the run-up in the caseload, especially for mental disorders - made the childhood component of the SSI program a target for reform during the welfare reform debates.

\section{The 1996 Reforms to the SSI Program}

Motivated in part by the perceived increase in the enrollment of children with apparently moderate disabling conditions, PRWORA changed the determination of childhood disability by providing a new statutory definition of disability determination for children applying for SSI. In addition, the law required regular continuing disability reviews for childhood cases, and that all children attaining the age of 18 be redetermined for eligibility under the adult disability criteria.

Under PRWORA, the rules for determining SSI program eligibility for disabled children became more restrictive. In terms of the childhood disability definition, the comparable severity criterion was replaced with a definition of disability unique to children: "a medically determinable physical or mental impairment, which results in marked and severe functional limitations" (SSA, 1997b). The legislation eliminated the IFA and required SSA to remove reference to "maladaptive behaviors" from the "personal/behavioral" domain of the childhood mental disorders listings because Congress believed that maladaptive behaviors were already evaluated under another domain (the "social" domain) and wanted to eliminate double-counting of the same limitations.

The law also provided that some children on SSI were subject to having their benefit status redetermined. Specifically, of the approximately one million children receiving SSI based on disability as 
of August 1996, the Social Security Administration (SSA) estimated that 288,000 children would need to have their eligibility redetermined under the new law. Children who were determined not to meet the new disability criteria were subject to losing their SSI benefits starting in July 1997 (although in practice, no children lost benefits before August 1997). Parents or guardians of children who were determined to no longer qualify for SSI could appeal the decision. ${ }^{4}$

In an analysis of SSA administrative data as of August 1999, three years after the law's passage, Karoly, Rogowski and Hirscher (2000) document that just over 100,000 childhood SSI participants - or about 10 percent of the SSI childhood caseload in August 1999-were determined to be no longer eligible for benefits under the new, more restrictive disability definition. Some of the terminated cases (just under 10 percent) were still under appeal as of August 1999 so the final number of terminations is likely to somewhat lower. However, some of these SSI childhood beneficiaries would have lost benefits anyway through normal program attrition (e.g., due to an increase in family income). Among those who lose benefits, the data through August 1999 suggest only a small fraction (less than 2 percent) subsequently reapplied and were granted SSI benefits. This suggests that the extent of return to the SSI rolls is likely to be modest.

\section{ANALYTIC FRAMEWORK}

A range of outcomes may be affected for the approximately 100,000 children that lost SSI childhood disability benefits following the passage of the 1996 reform legislation, including most directly family income and poverty status, but also indirectly other family-level decisions such as the work status of adults in the family and participation in other social safety net programs. The loss of SSI may have other effects on family and child well-being, including changes in health insurance coverage, child health, and family living arrangements. Data limitations preclude an analysis of all of these outcomes. Hence, in this section, we focus on the expected impacts of the reforms on three key outcomes of affected children and their families: income and poverty, employment status, and participation in other social welfare programs. These outcomes are among the most relevant for understanding the impact of the SSI changes on child and family well-being and they can be readily measured in the SIPP data.

\section{SSI Benefit Loss and Family Income and Poverty Status}

The loss of SSI due to the 1996 childhood disability reforms may affect family income and the family's poverty status. In two articles, Kearney, Grundmann and Gallicchio $(1994,1995)$ examined the poverty status of children on the SSI program using the 1990 SIPP. They found that SSI raised the income of many families with disabled children above the poverty threshold. They also found

${ }^{4}$ Benefits could continue while the decision was under appeal. Payments during the appeal period were subject to repayment if the child was found not to meet SSA disability criteria, but repayment could be waived if the claimant appealed for a repayment waiver in "good faith" (SSA, 1997a). 
considerable variation in the poverty status of households with children on SSI, with 24.2 percent with income below 75 percent of the poverty threshold, and 34 percent with income above 1.5 times the threshold. Poverty status among SSI households with children (including adult recipients) was related to the couple status of the household head, with single parents more likely to remain in poverty. For these families, SSI was a larger fraction of family income.

Another study provides insight into the poverty status of families on SSI prior to the 1996 reforms. Lukemeyer, Meyers, and Smeeding (1997), using the California Work Pays data, found that the SSI program lowers the poverty rate of families when income is counted net of the significant disabilityrelated out-of-pocket expenses. They found that 53.1 percent of AFDC recipients had out-of pocket disability-related expenses in the previous month. The average expense among those with expenses was $\$ 167$. They also estimated the contribution of these expenses to poverty rates and found that, counting AFDC, SSI and food stamps, 32 percent of families with severely disabled children receiving SSI had income below the poverty level. If the severely disabled child does not receive SSI, 75 percent have income below the poverty level. They also found evidence of higher mental disability-related expenses.

We would expect that the primary effect of the 1996 changes in the SSI childhood disability program would be on family income, and therefore the poverty status of families with children formerly on SSI. While children who leave SSI due to normal attrition typically do so because of an increase in family income, families who lost benefits due to the stricter disability definition in the 1996 PRWORA legislation would not necessarily experience the same income change. Predicting the magnitude of the change in income or poverty status for the families of affected children, or even the direction, requires a greater understanding of the determinants of SSI program participation, and its impact on related choices by the family. In particular, families may choose to replace the lost SSI by working more. Alternatively, the family may apply for and receive other cash and in-kind means-tested benefits, such as TANF and food stamps. Thus, the net effect on family income and poverty status is uncertain.

\section{SSI Benefit Loss and Labor Supply}

The understanding of the consequences of the loss of SSI can be considered in the context of a model of participation in an income-support program. Individuals are assumed to allocate time between work in the labor market and nonmarket time. Time in the labor market is productive: It provides income that can be used to purchase goods and services. Nonmarket time is also productive, since many valuable goods and services are produced at home. In addition, leisure is part of nonmarket time and is valued as well. Individuals choose how much time to spend working, and how much time to spend in nonmarket activities, depending on the value of time spent in each activity. For instance, the higher an individual's wage, the higher the relative value of time spent in market activities, so that additional time spent in the labor market is preferred. 
SSI provides income support to families whose income falls below a particular threshold. After a fraction of income is disregarded, the child's income plus income deemed from the parents is compared to the SSI federal benefit rate, and the difference is paid in a monthly benefit. As in any means-tested income support program, this lowers the value of time spent in the labor market, since earned income lowers the benefit.

The higher the benefit paid, the greater the incentive to choose to participate in the program rather than to work. Only a few studies explicitly examine the trade-off between labor force participation and program participation in the SSI program for parents of recipient children. Garrett and Glied (1997) estimate that the Sullivan vs. Zebley case had a significant negative impact on the employment of unmarried women without a high school education. However, since some of these women were previously collecting AFDC benefits, which allows the recipient to keep less earned income than SSI, the effect of the Zebley case was smaller in states with a low AFDC benefit. Kubik (1997) estimates that holding the AFDC benefit constant, a 10 percent increase in the SSI benefit leads 27,000 female heads of households to exit the labor force.

The trade-off between work and program participation for other income-support programs has been well documented. Moffitt (1992) reviews the work disincentive effects of the AFDC program. There is also a literature on the impact of the Social Security Disability Insurance (SSDI) program on the labor force participation of adult men, including studies by Parsons (1980) and Bound (1989). Temporary disability benefits for Workers' Compensation (WC) have been shown to increase the time out of work after a workplace injury (see, for instance, Meyer, Viscusi and Durbin, 1995.)

This literature suggests that the loss of SSI eligibility due to the 1996 childhood redeterminations will increase the labor supply of parents of those children. It is, however, difficult to predict the magnitude of the change in labor supply for at least two reasons. First, childhood disability imposes additional costs on the parents of disabled children that may make the transition to employment difficult. Second, as discussed below, the family may apply for and qualify for benefits under other income support programs. The generosity of these programs may affect labor supply as well. The overall impact on work effort is thus an empirical issue that can be considered in the analysis of the SIPP data.

\section{SSI Benefit Loss and Other Program Participation}

An important feature of the SSI program for children is that many of the recipients would also be eligible for the TANF program, formerly AFDC. ${ }^{5}$ Thus, those who lose SSI benefits may seek income support from TANF or other safety net programs (e.g., food stamps or general assistance). An economic framework can also be applied to the choice of programs. If eligible for both programs, a family will choose the program that provides the higher benefit. If there are costs associated with one program, such

${ }^{5}$ An individual cannot receive both TANF and SSI, although different members of the same family may receive both types of benefits if different family members qualify for both programs. 
as costs in terms of assembling information on your child's condition or stigma attached to identifying your child as disabled, then the greater the difference in benefits, the more likely the family will be willing to incur the costs to ensure eligibility for the higher benefit program.

In the post welfare reform era, with lifetime limits on TANF receipt and other requirements regarding work and so on, there are good reasons to expect program shifting from TANF to SSI (Stapleton et al., 1999). Earlier studies of welfare-SSI interactions suggest that some former AFDC/TANF participants will apply for SSI and qualify for the program in the post-TANF era (Garrett and Glied, 2000; Kubik, 2003; and Brady, Seto, and Meyers, 1998), and there is similar preliminary evidence of such transitions during the welfare waiver period (Schmidt and Sevak, forthcoming).

On the other hand, the evidence that families leaving SSI in the post-TANF era are moving to TANF is rather limited, although some of the evidence from the family interviews presented in Inkelas et al. $(1999,2000)$ suggests that families of disabled children who lose benefits may turn to TANF for income support. Given the evidence that the SSI caseload growth in the early 1990s was drawn, in part, from the AFDC rolls, it is reasonable to expect that some of the children found ineligible for SSI will participate in TANF.

However, the maximum 5-year lifetime limit on TANF receipt may dampen the trend toward increased TANF participation. Depending on a state's specific TANF program features and child welfare policies (e.g., eligibility, time limits, work requirement exemptions, foster care payments), more families in some states relative to others may turn to TANF after the child loses SSI. Whether or not TANF will be a continued source of income support for such children in the post welfare-reform period - and what time limits could apply — may contribute to the overall impact of the SSI reforms in a state.

\section{EMPIRICAL APPROACH}

The goal of the empirical analysis is to determine the impact of the loss of SSI as a result of the 1996 PRWORA legislation on family labor supply, welfare program participation, and income and poverty. To accomplish this, we adopt a modeling strategy that is designed to control for other factors besides the legislative change that may affect outcomes for children and their families. In this section, we outline the general modeling approach.

For the empirical model, we consider the differences in outcomes for two groups of children: children who retain their SSI benefits over some interval of time, $t_{0}$ to $t$; and children who lose their SSI benefits over the same interval of time, either because of normal attrition from the SSI program or because of a policy change, such as the 1996 PRWORA legislation. For example, if the interval of time were a one-month period before the welfare reform legislation is passed (e.g., July 1995 to August 1995), children in the first group would retain their benefits, while those in the second group would lose their benefits because of normal attrition. For a time interval after the 1996 welfare reform legislation is implemented (e.g., July 1998 to August 1998), children in the first group would retain their benefits while 
children in the second group would lose their benefits either because of normal attrition or because of the policy change.

We want to address the following question: All else equal, what is the effect of the 1996 PRWORA legislation on children in this second group, i.e., those who lose their benefits? To get an estimate of that effect, we need to control for other factors that may also affect the outcome of interest. If we only compared the difference in a given outcome (e.g., family income, labor supply) for children who keep their SSI benefits versus children who lose their SSI benefits in the second time interval (after the policy change), the difference would capture the effect of both the policy change and the impact of normal attrition. However, by using the experience of children who lost benefits in the period before the policy change as a comparison group, we can net out the effect of normal attrition and capture only the effect of the policy change. In essence, we are asking, how are the children who lost their benefits different from those who retained their benefits in the period after the policy change versus the period before the policy change?

This approach can be extended by using the group of SSI childhood beneficiaries unaffected by the reforms as an additional comparison group for the affected group in the post-reform period. In particular, we estimate models of the following form for child $i$ in location $g$ at time $t$ :

$$
\begin{aligned}
& Y_{i g t}=\beta_{0}+\beta_{1} \text { AFTER }+\beta_{2} \text { LOSESSI }+\beta_{3} \text { LOSESSI*AFTER }+\beta_{4} \text { AFFECTED*AFTER }+ \\
& \beta_{5} \text { LOSESSI*AFFECTED } * \text { AFTER }+\gamma \boldsymbol{Z}_{i g t}+\delta \boldsymbol{P}_{g t}+\varepsilon_{i g t}
\end{aligned}
$$

where $Y_{\text {igt }}$ is the outcome being examined, AFTER is a time indicator that is 1 after the legislation and 0 before, LOSESSI is an indicator for losing SSI benefits between $t_{0}$ and $t$ (those who keep their SSI benefits serve as the reference group), and AFFECTED is defined as the group of SSI childhood beneficiaries as of August 1996 who were potentially affected by the more narrow definition of childhood disability (i.e., those subject to redetermination). ${ }^{6}$ The model also includes controls for child and family characteristics, $\boldsymbol{Z}_{i g t}$, and a vector of location-specific variables, $\boldsymbol{P}_{g t}$ (e.g., economic indicators or policy variables). The error term, $\varepsilon_{i g t}$, is an appropriately specified model error term. Since the AFFECTED group is only identified in the post-reform period, this model differs slightly from a standard differencein-difference-in-difference (DDD) estimator. ${ }^{7}$

Table 1 shows the interpretation of the model in (1). The unaffected group in the pre-reform period serves as the comparison group for both the post-reform unaffected group and the post-reform

\footnotetext{
${ }^{6}$ Note that this model can be extended to include multiple time periods before the legislation is implemented to serve as controls.

${ }^{7}$ Since the AFFECTED group is not identified in the pre-reform period, we have dropped the AFFECTED indicator and the interaction term between LOSESSI and AFFECTED. These terms are collinear with terms included in the model.
} 
affected group (hence the same coefficients in the first row of each panel representing the pre-reform period). In equation (1), $\beta 3$ measures the net effect of the legislation for the unaffected group. Since the legislation should not have affected this group, this parameter should capture other changes that affected the outcome of interest for families with children that are not otherwise controlled for in the model. By comparison, $\beta_{3}+\beta 5$ measures the net effect of the policy change for the affected group. By differencing the net effect for the affected versus the unaffected group, $\beta 5$ captures the net effect of the legislation on the affected group holding all else constant, including the effect of normal attrition from the SSI rolls.

Thus, the difference (after versus before the legislation is implemented) in the difference (between those who keep versus those who lose SSI benefits) in the difference (between the affected and unaffected families with SSI childhood beneficiaries) is our preferred measure of the net impact of the legislation on family outcomes. By using the baseline (pre-reform, unaffected children) as a comparison group, we are essentially capturing the impact on the outcomes of interest of the excess benefit loss in the post-reform period. This excess benefit loss is attributable to the 1996 PRWORA reforms. The inclusion of other child- and family-level and location-specific controls, $\boldsymbol{Z}_{i g t}$ and $\boldsymbol{P}_{g t}$, means that the net impact of the legislation will be addressed for children and families who are similar in terms of their observable characteristics, such as race/ethnicity, family composition, or state economic and policy environment.

\section{SIPP DATA}

Data from the 1992, 1993 and 1996 SIPP panels, matched to SSA administrative records on SSI program participation, are used to implement the empirical modeling strategy. Among nationally representative longitudinal databases, the combination of multiple SIPP panels provides the largest sample sizes for analysis of disabled children and their families who participate in SSI both before and after the 1996 PRWORA changes (Reville, et al., 1998). The data also permit analyses of multiple outcomes. Moreover, the matched SSA data on SSI participation provide more accurate information on SSI program participation and who was affected by the 1996 reforms than the self-reported information available in the SIPP (Huynh, Rupp, and Sears, 2002). For purposes of evaluating the impact of the 1996 PRWORA legislation across a number of outcomes using a nationally representative database, the SIPP is the most suitable data source. In this section, we describe the SIPP data and the measures of the dependent variables and covariates. We conclude this section with a discussion of the sample sizes available for analysis and issues of statistical power.

\section{Data Description}

The SIPP is a nationally representative sample of U.S. households designed to collect detailed information over time on the demographic, social, and economic characteristics of families and individuals in the United States. For each SIPP panel, a sample of up to 39,000 households is interviewed every four months for up to 12 interviews. (The sample is divided into four rotation groups so that 
approximately one quarter of the sample is interviewed in each month.) At each interview, or wave, information is collected for the preceding four-month period, thereby covering up to a 48-month period in 12 interviews. In the early 1990s, two or more SIPP panels were being interviewed at the same time. Beginning with the 1996 SIPP and subsequent panels, only one panel was being interviewed at any given time.

The SIPP questionnaire instrument consists of a core questionnaire module that is given at each interview wave. The core module collects basic information on household and individual characteristics (updating the information with each subsequent wave), labor force status for household members age 15 and above, program participation for all household members and income recipiency and amounts. Most of this information is collected on a monthly basis for the four-month reference period that preceded the interview month.

Table 2 provides some information about the features of the 1992, 1993 and 1996 SIPP panels including the number of interview waves, initial sample size (number of households), and the period covered by the interviews. Across these three panels, the length varies from 9 waves (1993) to 12 waves (for 1996), with sample sizes between about 20,000 households and nearly 37,000 households. Together these panels cover the period from October 1991 through March 2000, sometimes with two panels covering the same time period.

The monthly SIPP data are matched at the individual level to monthly SSA administrative records on SSI program participation from the Supplemental Security Record (SSR), which is the master file for administration of the SSI program. The extract from the SSR follows the Longitudinal Extract Format and provides monthly data on SSI payment status and benefit amounts from the inception of the program in January 1974 to the present. Following the procedure used in SSA statistical reports on the SSI program, an individual is identified as a SSI recipient for months in which his or her combined federal SSI payment and federally administered state supplementary payment (if any) is greater than zero. ${ }^{8}$ Research has shown that using matched administrative records in this fashion provides more accurate estimates of SSI participation and benefit amounts than the self-reported information in SIPP (Huynh, Rupp, and Sears, 2002). In addition to the SSI benefit data, we match the monthly SIPP data to administrative records from the SSI children's welfare reform "universe" file. That file includes a record for all SSI children whose eligibility was subject to redetermination under PRWORA. ${ }^{9}$ From this file, we identify children in the affected group described above.

${ }^{8}$ The SSR does not contain information on state-administered supplementation of federal SSI benefits. Of the 45 states that pay optional state supplementary benefits, 29 are state administered, 11 are federally administered, and 5 are federally and state administered (SSA, 2001).

9 The "universe" file also contains records for the first cohort of SSI recipients who were subject to redetermination against the adult disability criteria during the year in which they reach 18 years of age. These age-18 redeterminations are an important, on-going component of PRWORA, but are not the focus of this paper. 
The empirical approach discussed in Section 4 requires identifying the sample of children that are receiving SSI benefits at time $t_{0}$ and their recipiency status at time $t$, with the ability to differentiate the affected group - those subject to redetermination under PRWORA — versus the unaffected group. This information comes from the matched SSA records. The outcome measures and child and family characteristics come from the SIPP. The resulting sample consists of the universe of children under age 18 in the SIPP that are ever recorded as receiving SSI in a month covered by the SIPP panel. Children can contribute multiple observations if they are observed in multiple SIPP waves. A child must be observed at least two consecutive months to enter the sample.

\section{Dependent Variable and Covariates from the SIPP}

The analysis focuses on five specific outcome measures that capture the three outcome domains of interest: labor supply, welfare program participation, and income and poverty status. In our preferred models, we measure outcomes at time $t$ one month after time $t_{0}$. In other words, conditional on being on SSI at time $t_{0}$, we model outcomes 1 month later as a function of whether SSI benefits are lost or retained during that interval. If the child is not observed at time $t$ due to attrition from the sample, they are lost from the sample for that interval.

One tradeoff with the length of the observation window is whether or not there is interest in examining the impact of SSI benefit loss both in the near term and in the longer term. The consequences of benefit loss may be very different immediately after benefit loss versus some months after termination. A longer window provides the opportunity to gauge whether the impact changes the longer the period without SSI benefits. Thus, in Section 6 below, we examine the sensitivity of the results to the use of a 4month, 6-month, and 12-month window. The drawback of the longer window is the loss of sample, both because fewer intervals can be analyzed and because some intervals are lost due to attrition from the SIPP sample.

In terms of the labor market, we model the employment status of the child's parents (mother or father only in single-parent households). The dichotomous measure of employment is set to one for children whose mother or father are working at time $t$. For program participation, we model participation in both AFDC/TANF and food stamps at time $t$. In each case, an indicator variable is set to 1 if the child's family receives benefits from the two programs, respectively.

Finally, we model both the income-to-poverty ratio (child's family income divided by the family's poverty threshold) and the dichotomous measure set to 1 for children in families whose income falls below the poverty threshold. Income is based on monthly cash income at time $t$. The income-to-poverty ratio adjusts for differences in family composition. A ratio less than one indicates that the family is poor based on the official poverty threshold.

A number of controls were included to measure child- and family-level characteristics at time $t$, the

vector $Z_{i g t}$ in equation (1) above. The child characteristics include controls for sex and race/ethnicity, 
which is categorized in four groups: white non-Hispanic (the reference group), Black non-Hispanic, Hispanic, and other non-Hispanic. Family headship status at time $t$ is categorized as no parents present (the reference group), mother only present, father only present, or both parents present. The highest grade completed of the child's father and mother is recorded as less than high school (the reference group), high school, or some college or higher. Controls are also included for the number of adults and the number of children in the family at time $t$.

\section{Economic and Policy Variables}

Equation (1) assumes a "before" PRWORA period (the reference period) and an "after" PRWORA period (measured by AFTER). In applying the model, three time periods are defined based on time $t$ to differentiate the pre-PRWORA period (up to July 1996), a PRWORA transition period (August 1996 to July 1997), and the post-PRWORA period (August 1997 and after). ${ }^{10}$ In the models we estimate, the prePRWORA period serves as the reference group so that all effects are measured relative to the prePRWORA period. Since the primary interest is in the effect of the post-PRWORA change, we focus on that effect relative to the pre-PRWORA period. This provides the sharpest contrast in the policy environment and separates out possible anticipatory effects during the transition period.

As noted in Section 4, the model also includes state-level economic and policy variables, the vector $\boldsymbol{P}_{\text {gt }}$. Data from other sources that capture the economic and policy environment at time $t$ were matched to the SIPP panels by state and year from 1992 to 2000 . To control for the business cycle, the state annual average unemployment rate of the civilian noninstitutionalized population 16 years of age and over is included as a control. Models were also estimated with year fixed effects to control for year-specific factors that are not already included in the models.

The generosity of the state AFDC/TANF program is measured by the monthly maximum combined benefit for a family of three (a parent with two children). Although the SSI federal benefit level is constant across states at a given point in time, the state supplementation of benefits introduces variation in actual benefit levels. Information on state-level SSI supplementation was taken from the SSA annual report titled State Assistance Programs for SSI Recipients (SSA, multiple years). Among the states that provide optional benefit supplementation, some do not provide supplemental benefits for disabled children. Thus, the state benefit supplement amount, if any, that applied for noninstitutionalized disabled children is recorded. ${ }^{11}$ In January 2000, for example, when the federal SSI benefit level was

\footnotetext{
${ }^{10}$ As discussed in Section 2, in the case of the SSI childhood disability program, children who were determined not to meet the new disability criteria were subject to losing their benefits starting in July 1997 although, in practice, the earliest date that benefits were ceased was August 1997. Thus, the transition period captures the time when the legislative changes were known but benefit cessations had not yet begun.

${ }^{11}$ We did not count a benefit supplement that only applied to blind children or children living in foster care or other specialized institutional arrangements.
} 
\$512 per month, the monthly state supplements for disabled children (among the states with a supplement) ranged from \$4.90 in Hawaii to \$114.39 in Massachusetts. Along with Massachusetts, California and Wisconsin consistently ranked as having more generous state supplementation of SSI for disabled children during the 1990s. The combined federal monthly SSI benefit amount plus the state supplement, if any, is the maximum available: the benefit amount may be reduced if the child or his or her family has positive countable income. This maximum SSI federal plus state benefit level serves as the measure of SSI program generosity. All benefit levels are adjusted for inflation using the Consumer Price Index (CPI-U-X1).

Given the other changes to the social safety net, we also include two measures to capture the preTANF waivers implemented by the states, as well as the implementation of state-specific TANF programs following the 1996 legislation. The two measures are set to 1 when a state implemented a waiver prior to 1996 or when the state TANF program was implemented after 1996. States that implemented their waiver or TANF programs part-way through a given year are assigned a fractional value between 0 and 1 . California, Michigan and New Jersey were the first states to implement waivers in 1992. By 1996, another 25 states had implemented waivers for all or part of that year. The transition to TANF took place during 1996 and 1997, with 28 states partially implementing TANF in 1996 and 33 states with full TANF implementation in 1997. All states had implemented the program by 1998. The measures we use were constructed by Schoeni and Blank (2000) and are used in their analysis of the impact of TANF on various economic outcomes.

For the 1992, 1993, and 1996 SIPP panels, nine smaller states (Alaska, Idaho, Iowa, Maine, Montana, North Dakota, South Dakota, Vermont, and Wyoming) are not uniquely identified in the data. Consequently, families on SSI at time $t_{0}$ in those states were dropped from the analysis file.

\section{Sample Sizes and Statistical Power}

For the one-month window, the final sample for the models consists of 915 children that received SSI at least one month in the SIPP. These cases, because they are observed over multiple months in the SIPP-SSA panels, contribute 21,187 matched pairs of months (time $t_{0}$ to $t$ ). ${ }^{12}$ A child may contribute up to 48 records (for the 1996 panel only) to the sample. ${ }^{13}$ For this sample, there are 362 cases of SSI benefit loss: 166 cases in the pre-reform period, 47 in the transition period, and 149 in the post-reform period. Benefit loss among children in the affected group totals 79 cases.

12 The final sample includes 4,699 child-month observations on 214 unique children from the 1992 SIPP, 4,389 child-month observations on 217 unique children from the 1993 SIPP, and 12,099 childmonth observations on 484 unique children from the 1996 SIPP.

13 All waves of SIPP data can potentially be used in each panel because SSI participation can be observed prior to the start of the SIPP panel using the administrative data. Since SSI participation is the only variable measured at $t_{0}$, all other variables are observed in the period covered by the SIPP panel defined as period $t$. The estimation procedure properly accounts for the repeated observations on the same child over time in calculating standard errors for the regression parameters. 
Given that the SIPP is a nationally representative sample and participation rates in the childhood SSI program are relatively low, one concern is whether the sample sizes are sufficient to measure the impact of the 1996 PRWORA legislation on family outcomes with any precision. ${ }^{14}$ In our sample, there are 1,455 child-month observations for 88 unique children in the affected group in the post-PRWORA period. About 58 percent of the unique child observations (or 51 unique children and 60 child-month cases) in the affected group lose SSI benefits in the post-PRWORA period over the one-month window. Inferential strength is further borrowed from the observed changes in SSI coverage for the unaffected group before the legislation became effective and after PRWORA. During the pre-PRWORA period, 11,127 child-month observations for the unaffected group contribute 166 cases of benefit loss, while another 5,161 child-month observations for the unaffected group contribute 89 cases of benefit loss in the post-PRWORA period. ${ }^{15}$

Power calculations reported in Reville, et al. (1998) suggest that a sample size of about 4,000 would be required to detect a 5 -percentage point difference in poverty rates (starting at 25 percent) between children whose benefits are terminated versus those that continue, assuming 10 percent of the sample loses benefits in the post-reform period. If the poverty rate for terminated children doubled (i.e., increased 25 percentage points), the required sample size would be only a few hundred cases.

Recognizing that the repeated observations on the same child over time reduces the effective sample sizes, the sample of over 1,455 child-wave observations in the post-reform period for the affected group and a benefit loss rate of nearly 58 percent should be adequate to detect moderate and large differences in outcomes between those children that lose their benefit versus those that do not. If the effect of the legislation on the outcomes of interest is small, the effect sizes may be evident in the point estimates but large standard errors on the estimated parameters will result in a lack of statistical significance.

\section{EMPIRICAL RESULTS}

The analysis of the SIPP data begins with a descriptive analysis, including modified DDD estimates based on a model with no control variables. We first discuss these findings and then turn to the full regression model results. A series of sensitivity analyses are discussed at the end of the section.

\section{Descriptive Results}

The first column of Table 3 presents descriptive statistics for the dependent variables and covariates for the sample of children on SSI at time $t_{0}$ - the sample for the DDD analysis - using a onemonth window. For this sample, about 43 percent of the sample has a working mother or father over the time period covered in the data. Nearly 40 percent of the children are in families that participate in

14 This would be less of a concern with a sample survey of the same size that overrepresented low income families or families with disabled children.

${ }^{15}$ In estimating the effect of the PRWORA reforms, we are not relying on the 47 cases of benefit loss out of 3,444 child-month observations in the TANF transition period. 
AFDC/TANF, while about one in two children are in families that receive food stamps benefits. On average, income is about 1.2 times the poverty threshold, while nearly 1 in 2 children are in families classified as poor. About half the sample observations fall into the pre-PRWORA time period, while just under one-third are in the post-PRWORA period, with the remainder in the PRWORA transition period. About 12 percent of the child-month observations represent cases in the affected group, i.e.,. those children subject to redetermination in the post-PRWORA period. Just under two percent of the childmonth observations result in SSI benefit loss.

In terms of child and family characteristics, just under 4 in 10 observations are girls. NonHispanic whites and blacks each make up about 40 percent of the sample, while Hispanics comprise about 17 percent of the sample. More than half the children are in families headed by a single mother, while about one-third have both parents present. Conditional on the mother being present (percentages not shown), 42 percent have less than a high school education, 36 percent have completed high school, while 22 percent have some college or more. The education distribution for fathers when they are present is similar. On average, children are in families with 1.8 adults and 2.8 children.

Over the sample period, the unemployment rate was relatively low, just under 5.6 percent on average. The maximum state SSI benefit (combined federal benefit and state supplement) for a disabled child exceeds the state AFDC/TANF benefit by about $\$ 140$ a month. About 18 percent of the sample observations are in states that had a major welfare waiver in effect, while about 42 percent of the sample observations are in states that had implemented the state's TANF provisions.

During the one-month observation window, about 2 percent of the child-month observations lose their SSI benefits ( 362 cases). The last two columns of Table 3 contrast the outcomes and control variables for those that keep SSI benefits versus those that lose SSI benefits. In general, the patterns are what would be expected if SSI loss was due to attrition as a result of no longer being eligible for SSI when the family's economic circumstances improved. For example, loss of SSI is associated with higher work effort, reduced participation in AFDC/TANF and food stamps, an increase in the income-to-poverty ratio, and a reduction in the poverty rate. Those that lose SSI do so at a higher rate among white children, children in two-parent families, children with more educated parents, and children in families with a greater number of adults and fewer children. SSI loss occurs in states and at times when unemployment is on average lower. The other policy variables show smaller differences across those who retain SSI benefits versus those that lose benefits. Consistent with the PRWORA reforms, the rate of SSI loss is highest in the post-PRWORA period and among those in the affected group.

Before implementing the DDD model in (1), Table 4 presents simple DDD estimators for the outcomes of interest using a one-month observation window with no control variables. For each outcome, the table shows the mean outcome for each time period (first three rows) for those that lose SSI benefits versus those that keep SSI benefits (first two columns). Results are shown first for the unaffected group (children in the pre-PRWORA period or the PRWORA transition and post-PRWORA periods not subject 
to redetermination) and then for the affected group (children in the PRWORA transition and postPRWORA periods subject to redetermination). For the unaffected and affected groups respectively, the differences in outcomes by time period (post-PRWORA versus pre-PRWORA) and by benefit status (lose SSI versus keep SSI) are shown in the final columns and rows, respectively. The DDD estimator, highlighted with a single-line border, considers the difference between the affected and unaffected groups in the difference in the post- versus pre-PRWORA periods of the difference in outcomes for those that lose SSI benefits versus those that keep them. The standard errors for the DDD estimator (and hence the statistical tests) are calculated using the Huber correction to account for the clustering of the observations (i.e., the multiple observations for each child).

Consider first the results for whether the mother or father is working. For the unaffected and affected groups, SSI loss is associated with a higher rate of employment in all time periods. For the unaffected group, there is virtually no change in the increase in employment rates associated with SSI benefit loss in the post-PRWORA versus the pre-PRWORA period (there is a slight, 1-percentage point, decline from a 35-percentage point increase to a 34-percentage point increase). For the affected group, there is a 31-percentage point decline in the probability that the mother or father is working in moving from the pre-PRWORA period to the post-PRWORA period (from a 35-percentage point increase to a 5percentage point increase). Thus the DDD estimator is negative and statistically significant, and indicates a 30-percentage point decline in the likelihood of employment in the month following benefit loss associated with the excess benefit loss in the post-PRWORA period attributable to the policy change. In other words, whereas benefit loss associated with normal attrition from the SSI childhood disability rolls is associated with an increase in employment of the child's mother or father, the benefit loss associated with the 1996 redeterminations is associated with a substantially reduced employment propensity among affected families.

In terms of participation in other social welfare programs, a parallel pattern is evident. Across both unaffected and affected groups and all time periods, the loss of SSI is associated with a reduction in reliance on AFDC/TANF and food stamps. Notably, among those who retained SSI benefits, the propensity to receive social welfare benefits fell in moving from the pre-PRWORA period to the postPRWORA period, consistent with the overall caseload declines in AFDC/TANF and food stamps over this time period. The DDD estimator suggests that the 1996 policy change resulted in increased reliance in the short-term on AFDC/TANF, with a 10-percentage point increase in the propensity to receive AFDC/TANF benefits for affected families of children that lost SSI childhood benefits in the postPRWORA period. In this case, the DDD estimator is somewhat less precisely estimated (consistent with the smaller effect size). The effect size for food stamps use is considerably larger (and more precisely estimated): an estimated 23-percentage point increase in the propensity to use food stamps within a onemonth window associated with the loss of SSI childhood benefits in the post-PRWORA period. 
Table 4 also shows the DDD estimator for the income-to-poverty ratio and an indicator that income falls below the poverty threshold. For the unaffected group, SSI benefit loss is associated with an increase in income, consistent with their observed increase in employment propensity. That effect increases in going from the pre-PRWORA to the post-PRWORA period. For the affected group, the consequences of SSI benefit loss turn negative in the post-PRWORA period indicating that income relative to the poverty threshold fell among those who lost benefits in the post-PRWORA period. As a result, the DDD estimator is negative and significant, indicating an effect size of 0.8 or a fall in income equal to 80 percent of the family poverty threshold. Consistent with this result, the poverty indicator shows a significant increase of 18-percentage points associated with the excess benefit loss among affected families in the post-PRWORA period.

In sum, without controlling for other observable child-, family-, or state-level factors that might affect the outcomes of interest, the point estimates for the simple DDD estimators suggest that as a result of the loss of SSI childhood disability benefits due to the tighter eligibility requirements in the 1996 PRWORA legislation, families were less likely in the short-run to be working and more likely to rely on TANF and food stamps. Compared with children in families that lost benefits due to normal attribution, the excess benefit loss in the post-PRWORA period among children affected by the redeterminations is also associated with a lower level of family income and a higher poverty rate. These effects are statistically significant at the 5 percent level or better with the exception of the AFDC/TANF result, which is significant at the 10 percent level. We now consider whether these findings are robust to the inclusion of other controls in the model, including child and family background characteristics and measures of the state economy and policy environment.

\section{Regression Results}

Tables 5 to 9 extend the simple DDD estimator presented in Table 4, with the addition of controls for child- and family-level characteristics and state- and year-specific variables. With the exception of the model for the income-to-poverty ratio, which is estimated using OLS, all models are estimated using a probit specification given the dichotomous outcome measure. Marginal effects and their standard errors are reported rather than probit coefficients, although tests of statistical significance are based on the underlying model coefficients. For each outcome, the tables report three model specifications. The first model has no controls, so the estimated coefficient on the three- way interaction term highlighted with a single-line border (corresponding to LOSESSI *AFFECTED * AFTER in equation (1) above) is the modified DDD estimator corresponding to the estimator reported in Table 4. Since the Table 4 results were based on estimating a linear model, the DDD estimator in Model 1 in Tables 5 to 9 will differ from the equivalent estimator reported in Table 4 due to the differences in functional form (with the exception of the income-to-poverty measure, which is also estimated using OLS in Table 8). The other coefficients on the main effects and interaction terms have the interpretation summarized in Table 1. 
The second model in each table adds child- and family-level controls for sex, race/ethnicity, family headship status, mother and father education, and family composition. These are all factors that can be expected to explain variation in employment, program participation, and family income and poverty status. The third model adds year-fixed effects, as well as the state-level unemployment rate and policy variables. As with the results in Table 4, all standard errors have been adjusted for clustering in the sample (i.e., repeated observations on the same family) using the Huber correction.

In the remainder of this subsection, we discuss the results for each of the three outcome domains: employment status, program participation, and income and poverty status. The primary interest is in the DDD estimator, the coefficient on the three-way interaction term. We discuss other model coefficients as well. A sensitivity analysis follows in the next subsection.

Employment status. Table 5 presents the estimated marginal effects for the three probit specifications of the probability model that the family mother or father is working at time $t$. The first column replicates the simple DDD estimator with no controls reported in Table 4 . With the nonlinear specification, the estimator in Table 5 indicates that the loss of SSI benefits for affected children is associated with a statistically significant 27-percentage point reduction in the likelihood of parental employment in the post-reform period, a slight reduction from the 30-percentage point effect reported in Table 4 based on a linear model. The addition of family-level covariates in the second model reduces the magnitude of the estimated effect on employment to 15 percentage points. Among the child- and familylevel variables in the model, the employment probability of the family mother or father is significantly related to family headship, parental education, and number of children. In particular, the employment rate is lower for families with a lone male head and as the number of children increases. The employment propensity increases with additional years of schooling of either parent.

The addition of year-fixed effects and state-level variables in Model 3 does little to change the magnitude and significance of the coefficients on the family-level variables. The estimated effect of the 1996 legislation on families that lose childhood SSI benefits increases slightly to 16 percentage points and remains statistically significant. With the exception of the AFDC/TANF benefit level, which is negatively related to the employment propensity as expected, the policy variables are not statistically significant.

Program participation. Models for AFDC/TANF and food stamps participation are reported in Tables 6 and 7, respectively. Again, the first column in each table shows the same DDD estimator reported in Table 4, albeit with a nonlinear specification. Looking across the rows of Tables 6 and 7 at this coefficient shows that the estimated effect of PRWORA on program participation is quite consistent across model specifications. In the case of AFDC/TANF participation, the models indicate that the loss of childhood SSI benefits in the post-PRWORA period is associated with a higher propensity of receiving benefits by 19 to 21 percentage points, although the p-values for the coefficients across the three models indicate less precision as successive controls are added ( $\mathrm{p}=0.053,0.100$ and 0.107 in Models 1 to 3, 
respectively). Note that the magnitude in the probit models is about twice the size of that reported in Table 4 for the linear model. In the case of participation in the Food Stamps Program, the effect in Table 7 is statistically significant and indicates a higher propensity of benefit receipt equal to 25 to 28 percentage points depending on the model, an estimate that is somewhat higher than the 23 percentage points reported in Table 4.

The coefficients on the other variables in the AFDC/TANF and food stamps models are generally similar and accord with expectations. Focusing on Model 3, blacks and mother only families are consistently more likely to participate in both programs relative to their respective reference groups, while families with both parents present are also more likely to participate in food stamps. Participation rates for both programs fall with the education of the parents and the number of adults, and rise with the number of children. AFDC/TANF participation rises with the benefit level and falls with the implementation of TANF. Food Stamp participation rises with the unemployment rate.

Income and poverty status. Tables 8 and 9 present the equivalent models for income relative to the poverty threshold and the indicator of poverty status. In the case of the income-to-poverty ratio, the inclusion of additional control variables in the model reduces the effect size from the simple DDD estimator in the first column of Table 8 , from -0.8 to approximately -0.5 . The effect size falls in Model 2 with the addition of family background variables that explain a substantial amount of the variation in the income-to-poverty ratio. The addition of other controls in the model does little to alter the effect size. In all models, the effect is statistically significant at the 1-percent level.

Many of the coefficients on the other variables in the income model are statistically significant, often at the one-percent level. Blacks and Hispanics have lower income-to-poverty ratios compared with whites. Although the income-to-poverty ratio is not significantly related to family headship, it increases with the education level of the mother and father. The income-to-poverty ratio also rises with the number of adults in the family and falls with the number of children. These effects all accord with what we know about the relationship between family incomes and family demographics, structure and human capital. Of the state-level economic and policy variables, only the AFDC/TANF benefit level is marginally significant, with a positive relationship to income.

In the models of poverty status in Table 9, the estimated effect size for the DDD estimator falls with the addition of other covariates in the model and loses significance. In contrast to the 20-percentage point effect in Model 1 (slightly above the effect estimated in the linear model reported in Table 4), the effect is half as large when all the controls are included in Model 3, largely as a result of controlling for the child- and family-level characteristics in Model 2. As the effect size falls, the p-values increase so that in Model 3, the coefficient is not statistically significant and has a p-value of 0.24 . The coefficients on the other variables in the poverty model mirror those seen for income, as would be expected.

In sum, the preferred Model 3 specification indicates that the excess benefit loss associated with the 1996 PRWORA reforms that restricted SSI eligibility was associated with a significantly lower level 
of employment among affected families, a higher level of food stamp use, and a lower level of income, all in the first month following benefit loss. The magnitudes of these estimated effects are sizeable. For example, the fall in the income-to-poverty ratio equals approximately 53 percent of the poverty threshold. For a family with one adult and two children in 1999 , the poverty threshold equaled $\$ 13,423$. Thus, the loss of SSI childhood benefits in the post-reform period is associated with a decrease in annual family income for a family of three of about $\$ 7,000$ or about $\$ 580$ per month. This is slightly higher than the average state maximum SSI benefit per disabled child of just over $\$ 500$ per month (see Table 3). The estimated increase in AFDC/TANF use and increase in poverty rates are consistent with these other results and sizeable in magnitude, but they are not statistically significant at conventional levels. Given the statistical power considerations discussed above, it is not surprising that with a relatively smaller effect size, the coefficients in the AFDC/TANF utilization and poverty models are not statistically significant at conventional levels.

\section{Sensitivity Analysis}

We conducted a number of sensitivity analyses to gauge the robustness of the results to alternative model specifications. In the remainder of this section, we discuss two sensitivity analyses for the outcomes of interest: one that examines the sensitivity of the estimated policy impact to the length of the horizon - using 4-, 6- and 12-month windows — and a second that considers the impact of the 1996 reforms based on the DD estimator.

Longer observation windows. As noted in Section 5, the one-month observation window captures the immediate impact of a loss of SSI benefits on the outcomes of interest. We also estimated the preferred DDD specification (Model 3 with full controls) for all outcomes using 4-, 6- and 12-month windows. These alternative windows provide some evidence of the impact of SSI benefit loss over a somewhat longer interval of time, although families and children may experience effects even beyond this short- to medium-term horizon. These results are reported in the second through fourth columns of Table 10. Depending on the outcome there are several differences between the results as the length of the observation window increases, with several sign reversals, although none of the effects are statistically significant at the 5 percent level in either the 6- or 12-month windows (as might be expected given the smaller sample sizes available using longer observation windows).

These results are suggestive that there may be differences in the short-run versus medium-run impact on families of losing SSI childhood benefits in the post-reform period. They are not definitive however: any differences in the estimates in moving from the 1-month to the 12-month windows should be interpreted cautiously given the imprecise estimates. In the case of employment, the results suggest that the negative effect persists beyond the effect observed in the first month, with an estimated impact that is nearly as large 12 months after benefit loss (although only significant at the 10 percent level). It is notable that the 4-month window suggests an even larger impact while the 6-month window is the 
smallest. In terms of benefit receipt, the impact on the receipt of AFDC/TANF remains positive but diminishes in size, with a 12-month impact estimate that is about half the size of the 1-month estimate, although none are statistically significant. In contrast, the positive impact on food stamp receipt shows no attenuation over a longer horizon, with a point estimate at the 12-month horizon that exceeds that for the 1-month horizon (although the effect is no longer statistically significant). The impact of benefit loss on the income and poverty measures shows the greatest attenuation, with a reversal of sign as of the 12month window, suggesting a longer-term positive effect on the income-to-poverty measure and a negative effect on the poverty rate, although again neither estimate is statistically significant.

The persistence of the negative impact on employment of the family mother or father at the same time that the effect on income and poverty changes sign is puzzling, although again the lack of statistical significance suggests caution in placing too much weight on these results. Given that the propensity for AFDC/TANF receipt is not significantly higher and since food stamp receipt is not included in the measure of family income (although the impact on food stamp receipt remains equally large over time), it is not clear what source of income can account for the estimated changes in the income impact over time. Since the income and poverty measures account for family size, it is possible that family living arrangements are changing in such a way as to add other adult earners to the family unit (e.g., through marriage on the part of single parents) or to subtract children from the family unit (e.g., through foster care or other care arrangements). It also is possible that other family members became SSI recipients during the 12-month window. Approximately 38 percent of SSI children live in families with more than one SSI recipient (Koenig and Rupp, forthcoming); however, the dynamics of SSI entry and exit among other family members are not well understood. Analysis of this issue is left to future research.

DD estimator. In Section 4, the DDD estimator was introduced in equation (1). An alternative model, the difference-in-difference (DD) estimator, does not make the distinction between affected and unaffected SSI childhood recipients so that $\beta_{3}$, the coefficient on the interaction LOSESSI*AFTER, becomes the parameter of interest in the following specification:

$$
Y_{i g t}=\beta_{0}+\beta_{1} A F T E R+\beta_{2} L O S E S S I+\beta_{3} L O S E S S I * A F T E R+\gamma \boldsymbol{Z}_{i g t}+\delta \boldsymbol{P}_{g t}+\varepsilon_{i g t}
$$

where the variables in (2) are defined as before in (1).

The final column of Table 10 presents the results from this model. For each of the outcomes, the estimated impact is attenuated in the DD model relative to the preferred DDD model in the first column, although the decrease is relatively small for the employment and poverty models. Given the smaller impact sizes, the p-values also increase so that only the coefficient in the employment model remains statistically significant at conventional levels. These results demonstrate that additional statistical power is gained from distinguishing between the unaffected and affected groups in the post-reform period. 


\section{CONCLUSIONS}

This analysis of the SIPP data was designed to gain insights into the well-being of children and families who lost SSI benefits as a result of the 1996 PRWORA legislation. As noted at the outset of this paper, the SIPP data, matched with SSA administrative records on SSI program participation, provide the best opportunity to track a nationally representative sample of noninstitutionalized childhood SSI beneficiaries over time to consider at least the short- and medium-term impact of the legislative changes. Our analysis approach considers the impact of the excess benefit loss associated with the 1996 reforms that introduced a more restricted definition of eligibility for childhood SSI benefits. We compare outcomes for families of children who lost SSI benefits in the post-reform period with those who retained benefits, netting out of the effect of benefit loss associated with normal program attrition. We further examine the effects for those affected by the 1996 reforms - those children with disability diagnoses that required a redetermination of their eligibility for SSI benefits - versus those children with diagnoses that remained unaffected by the reforms.

Our results indicate that the excess benefit loss associated with the 1996 reforms was associated with a lower propensity (by 16 percentage points) for the family mother or father to be working, compared with families that lost benefits due to normal attrition. At the same time, the propensity to use food stamps was higher (by 26 percentage points) and family income was lower (by 53 percent of the poverty threshold). The propensity to use AFDC/TANF and to have income below the poverty threshold was also higher (by 19 percentage points and 11 percentage points, respectively) but neither effect was statistically significant at conventional levels ( $p$-values of 0.11 and 0.24 , respectively). These impacts are all measured as of one month after benefit loss. When a longer horizon is examined, there is some evidence that the employment effect and propensity to use food stamps persist at approximately the same magnitude up to 12 months after benefit loss, while the other effects are attenuated with time, even to the point where the effects on income and poverty change sign. However, most of these results are imprecisely estimated.

While the SIPP data have the advantage of a nationally representative sample, the sample sizes are relatively small when the focus is on disabled children receiving SSI benefits. Consequently, the SIPP sample sizes were expected to be large enough to estimate fairly precise effects of the1996 reforms if the impact sizes were large, and possibly even moderate-sized impacts could be precisely estimated as well. But if the policy impacts were smaller, the SIPP would not provide much power to precisely estimate such modest effects. The analysis has largely born out this expectation. Generally, the results are statistically significant when a one-month observation window is used but the estimates are less precisely estimated as the length of the observation window increases. Outcomes such as employment, with consistently large impact estimates, remain statistically significant across specifications. However, other outcomes, such as the poverty rate, where the impact estimates are smaller do not always have statistically significant effects. Nevertheless, the relative stability of the results across model specifications and the 
accord between the different outcome measures provides greater confidence regarding the likely direction and magnitude of the impact of the legislation in terms of family work effort, participation in other social welfare programs, and income and poverty status.

The results presented in this paper largely accord with the findings from a complementary qualitative analysis based on a small number of semi-structured interviews conducted in 1998 and 1999 in four states with families that lost SSI benefits due to the 1996 reforms (Inkelas et al., 1999, 2000). For example, while some families reported they had returned to work or increased their work effort in response to the policy change, they were not any more likely to be working by the time of the second interview in 1999 compared with 1998. This suggests that there may have been a limit to the labor market response to the benefit loss, particularly for families where the child's disability creates a barrier to a parent's employment. Other families that were able to work when they received SSI benefits may no longer have been able to do so when the benefit payments stopped. This might have been due to problems with childcare or access to needed medical services that interfered with the parent's ability to work. In terms of other social welfare programs, Inkelas et al. $(1999,2000)$ report that many families indicated that they viewed their ability to increase their reliance on TANF benefits as short-lived given the time limits now attached to benefit receipt. Thus, the increased reliance on non-SSI transfer payments, especially TANF, may have declined even further beyond the medium-term horizon examined in this paper.

Finally, the family interviews in Inkelas et al. in both rounds found examples of families that experienced an income increase, but also families with an income decrease, with the bulk of the families in the latter category. Because precise income data before and after benefit loss were not collected as part of the family interviews conducted by Inkelas et al., the findings from those interviews cannot be fully reconciled with the SIPP-based findings presented here. Moreover, the SIPP analyses leave open the question as to the longer-term impact of the policy change on family income, beyond the 12-month horizon examined in this analysis. Families that lose SSI benefits may be vulnerable to income declines due to limited earnings capacity, fluctuations in earnings, or the time limits in other welfare programs. Depending upon the severity of the child's disability, there are also concerns about health insurance coverage and access to medical care, as well as any longer term impacts on child health. These issues remain to be explored in further research 


\section{REFERENCES}

Aron, L. Y., Pamela J. Loprest, and C. Eugene Steuerle, Serving Children with Disabilities, Washington, D.C.: Urban Institute Press, 1997.

Bound, John, "The Health and Earnings of Rejected Disability Insurance Applicants," American Economic Review, 79, 1989.

Brady, Henry E., Eva Seto, and Marcia Meyers, "Tracking the Impact of SSI Program Changes: The Impact of the Zebley Decision on Transition into SSI in California," UC Data Working Paper \#13, 1998.

Garrett, A. Bowen and Sherry. Glied, "The Effect of U.S. Supreme Court Ruling Sullivan v. Zebley on Child SSI and AFDC Enrollment: A Natural Experiment," Princeton, New Jersey.: Robert Wood Johnson Foundation, mimeo, March 1997.

Garrett, Bowen and Sherry Glied, "Does State AFDC Generosity Affect Child SSI Participation?" Journal of Policy Analysis and Management, 19(2), 2000, pp. 275-295.

General Accounting Office (GAO), Social Security: New Functional Assessments for Children Raise Eligibility Questions, GAO/HEHS-95-66, 1995a.

General Accounting Office (GAO), Supplemental Security Income: Recent Growth in the Rolls Raises Fundamental Program Concerns, Statement of Jane L. Ross before Subcommittee on Human Resources, House Committee on Ways and Means, GAO/T-HEHS-95-67, January 27, 1995b.

Huynh, Minh, Kalman Rupp, and James Sears, "The Assessment of Survey of Income and Program Participation (SIPP) Data Using Longitudinal Administrative Records," SIPP Working Paper \#238, Washington, D.C.: U.S. Census Bureau, 2002.

Inkelas, Moira, Melissa Rowe, Lynn A. Karoly, and Jeannette A. Rogowski, Policy Evaluation of the Effects of the 1996 Welfare Reform Legislation on SSI Benefits for Disabled Children: First Round Case Study Findings, DRU-2017, Santa Monica, California: The RAND Corporation, June 1999.

Inkelas, Moira, Melissa Rowe, Lynn A. Karoly and Jeannette A. Rogowski, Policy Evaluation of the Effects of the 1996 Welfare Reform Legislation on SSI Benefits for Disabled Children: Second Round Case Study Findings, DRU-2224-SSA, Santa Monica, California: The RAND Corporation, May 2000.

Karoly, Lynn A., Randall A. Hirscher, and Jeannette A. Rogowski, A Descriptive Analysis of the SSI Childhood and Age-18 Disability Redetermination Process: Results Through August 28, 1999, DRU2328, Santa Monica, California: The RAND Corporation, August 2000.

Kearney, John R., Herman F. Grundmann and Salvatore J. Gallicchio, "The Influence of Social Security Benefits and SSI Payments on the Poverty Status of Children," Social Security Bulletin, 57(2), Summer 1994, pp. 27-43.

Kearney, John R., Herman F. Grundmann and Salvatore J. Gallicchio, "The Influence of OASDI and SSI Payments on the Poverty Status of Families with Children," Social Security Bulletin, 58(3), Fall 1995, pp. 3-14. 
Koenig, Melissa and Kalman Rupp, "SSI Recipients in Households and Families with Multiple Recipients: Prevalence and Poverty Outcomes," Social Security Bulletin, forthcoming.

Kubik, Jeffrey D., "Is Disability Endogenous? The SSI Disability Program and the Health of Children," MIT, mimeo, November 1997.

Kubik, Jeffrey D., "Fiscal Federalism and Welfare Policy: The Role of States in the Growth of Child SSI," National Tax Journal, 56(1), March 2003 (Part 1), pp. 61-79.

Lukemeyer, Anna, Marcia K. Meyers, and Timothy M. Smeeding, "Expensive Children in Poor Families: Out-of-Pocket Expenditures for the Care of Disabled and Chronically Ill Children and Welfare Reform," Center for Policy Research Income Security Policy Series No. 17, Syracuse University, August 1997.

Meyer, Bruce, W. Kip Viscusi, and David L. Durbin, "Workers' Compensation and Injury Duration: Evidence from a Natural Experiment," American Economic Review 85(3), June 1995, pp. 320-340.

Moffitt, Robert, "Incentive Effects of the U.S. Welfare System: A Review," Journal of Economic Literature, 30(1), March 1992, pp. 1-61.

National Commission on Childhood Disability, Report to Congress of the National Commission on Childhood Disability Supplemental Security Income for Children with Disabilities, Social Security Administration: Washington D.C., 1995.

Parsons, Donald O., "The Decline of Male Labor Force Participation," Journal of Political Economy, 88(1), February 1980, pp. 117-134.

Reville, Robert, Moira Inkelas, Jeannette A. Rogowski, and Lynn A. Karoly, Data Sources to Evaluate the Effect of the Welfare Reform Legislation on Disabled Children, DRR-1815-SSA, Santa Monica, California: The RAND Corporation, February 1998.

Rupp, Kalman and David Stapleton, "Determinants of the Growth in the Social Security Administration's Disability Programs-An Overview," Social Security Bulletin, 58(4), Winter 1995, pp. 43-70.

Schmidt, Lucie and Purvi Sevak, "AFDC, SSI and Welfare Reform Aggressiveness: Caseload Reductions vs. Caseload Shifting," Journal of Human Resources, forthcoming.

Schoeni, Robert F., Rebecca M. Blank, "What Has Welfare Reform Accomplished? Impacts on Welfare Participation, Employment, Income, Poverty, and Family Structure", National Bureau of Economic Research Working Paper \#7627, March 2000.

Social Security Administration (SSA), Disability Evaluation Under Social Security ("The Blue Book"), Washington, D.C.: Social Security Administration, 1995.

Social Security Administration (SSA), Review of SSA 's Implementation of New SSI Childhood Disability Legislation, Washington, D.C.: Social Security Administration, December 17, 1997a.

Social Security Administration (SSA), Welfare Reform and SSI Childhood Disability: A Factsheet from Social Security, Washington, D.C.: Social Security Administration, $1997 \mathrm{~b}$.

Social Security Administration (SSA), State Assistance Programs for SSI Recipients, Washington, D.C.: Social Security Administration, 2001, various years. 
Social Security Administration (SSA), SSI Annual Statistical Report 2002, Washington, D.C.: Social Security Administration, August 2003.

Stapleton, D., M. Fishman, G. Livermore, D. Wittenburg, and A. Tucker, Policy Evaluation of the Overall Effects of Welfare Reform on SSA Programs - Final report, Washington, D.C.: The Lewin Group, Inc., April 1999.

Sullivan v. Zebley, 110 Supreme Court 885, 1990. 
Table 1

Interpretation of Coefficients in Model

\begin{tabular}{|c|c|c|c|}
\hline Not Affected & Keep SSI Benefits & Lose SSI Benefits & $\begin{array}{c}\text { Difference } \\
\text { [Lose - Keep] }\end{array}$ \\
\hline Before Policy Change & $\beta_{0}$ & $\beta_{0}+\beta_{2}$ & $\beta_{2}$ \\
\hline After Policy Change & $\beta_{0}+\beta_{1}$ & $\beta_{0}+\beta_{1}+\beta_{2}+\beta_{3}$ & $\beta_{2}+\beta_{3}$ \\
\hline $\begin{array}{c}\text { Difference } \\
\text { [After - Before] }\end{array}$ & $\beta_{1}$ & $\beta_{1}+\beta_{3}$ & $\beta 3$ \\
\hline Affected & Keep SSI Benefits & Lose SSI Benefits & $\begin{array}{c}\text { Difference } \\
\text { [Lose - Keep] }\end{array}$ \\
\hline Before Policy Change & $\beta_{0}$ & $\beta_{0}+\beta_{2}$ & $\beta_{2}$ \\
\hline After Policy Change & $\beta_{0}+\beta_{1}+\beta_{4}$ & $\begin{array}{c}\beta_{0}+\beta_{1}+\beta_{2}+\beta_{3} \\
+\beta_{4}+\beta_{5}\end{array}$ & $\beta_{2}+\beta_{3}+\beta_{5}$ \\
\hline $\begin{array}{c}\text { Difference } \\
\text { [After - Before] }\end{array}$ & $\beta_{1}+\beta_{4}$ & $\beta_{1}+\beta_{3}+\beta_{4}+\beta_{5}$ & $\beta 3+\beta 5$ \\
\hline $\begin{array}{c}\text { Difference } \\
\text { [Affected - Not Affected] }\end{array}$ & $\beta_{4}$ & $\beta_{4}+\beta_{5}$ & $\beta 5$ \\
\hline
\end{tabular}


Table 2

Features of 1992, 1993 and 1996 SIPP Panels

\begin{tabular}{lccc}
\hline \hline & \multicolumn{3}{c}{ SIPP Panel } \\
\cline { 2 - 4 } & 1992 & 1993 & 1996 \\
\cline { 2 - 4 } SIPP interview waves & 10 waves & 9 waves & 12 waves \\
Initial sample size (number of households) & 19,600 & 19,900 & 36,700 \\
Period covered & October 1991- & October 1992- & January 1996- \\
& April 1995 & December 1995 & March 2000 \\
\hline \hline
\end{tabular}


Table 3

Descriptive Statistics for 1992, 1993 and 1996 SIPP Panel Samples for Child SSI Beneficiaries

\begin{tabular}{|c|c|c|c|}
\hline & \multicolumn{3}{|c|}{ Child SSI Beneficiary } \\
\hline & Total & Keep SSI & Lose SSI \\
\hline \multicolumn{4}{|l|}{$\underline{\text { Outcomes }}$} \\
\hline Family mother or father employed & 0.4259 & 0.4207 & 0.7265 \\
\hline Family receives AFDC/TANF & 0.3783 & 0.3818 & 0.1768 \\
\hline Family receives food stamps & 0.5174 & 0.5214 & 0.2873 \\
\hline Family income-to-poverty ratio & 1.2385 & 1.2305 & 1.6982 \\
\hline Family income below poverty threshold & 0.4798 & 0.4831 & 0.2873 \\
\hline \multicolumn{4}{|l|}{ Covariates } \\
\hline \multicolumn{4}{|l|}{ Time interval } \\
\hline Pre-PRWORA & 0.5252 & 0.5263 & 0.4586 \\
\hline PRWORA transition & 0.1626 & 0.1631 & 0.1298 \\
\hline Post-PRWORA & 0.3123 & 0.3105 & 0.4116 \\
\hline Affected group & 0.1232 & 0.1215 & 0.2182 \\
\hline Lose SSI & 0.0171 & 0.0000 & 1.0000 \\
\hline Female [Male] & 0.3685 & 0.3683 & 0.3840 \\
\hline \multicolumn{4}{|l|}{ Race/ethnicity } \\
\hline [White non-Hispanic] & 0.4145 & 0.4116 & 0.5829 \\
\hline Black non-Hispanic & 0.3926 & 0.3945 & 0.2790 \\
\hline Other non-Hispanic & 0.0261 & 0.0259 & 0.0359 \\
\hline Hispanic & 0.1668 & 0.1680 & 0.1022 \\
\hline \multicolumn{4}{|l|}{ Family headship } \\
\hline [No parent present] & 0.0948 & 0.0958 & 0.0359 \\
\hline Mother only present & 0.5452 & 0.5487 & 0.3481 \\
\hline Father only present & 0.0276 & 0.0277 & 0.0193 \\
\hline Mother and father present & 0.3324 & 0.3278 & 0.5967 \\
\hline \multicolumn{4}{|l|}{ Mother education } \\
\hline [Less than high school or mother not present] & 0.4939 & 0.4965 & 0.3425 \\
\hline High school & 0.3148 & 0.3145 & 0.3315 \\
\hline Some college or more & 0.1913 & 0.1890 & 0.3260 \\
\hline \multicolumn{4}{|l|}{ Father education } \\
\hline [Less than high school or father not present] & 0.7928 & 0.7972 & 0.5414 \\
\hline High school & 0.1194 & 0.1181 & 0.1934 \\
\hline Some college or more & 0.0878 & 0.0848 & 0.2652 \\
\hline Number of adults in family & 1.7551 & 1.7528 & 1.8867 \\
\hline Number of children in family & 2.8087 & 2.8132 & 2.5497 \\
\hline State unemployment rate & 5.5901 & 5.5943 & 5.3453 \\
\hline State mo. max. AFDC/TANF benefit $(/ 100)$ & 3.7079 & 3.7071 & 3.7531 \\
\hline State mo. max. SSI benefit $(/ 100)$ & 5.0942 & 5.0946 & 5.0698 \\
\hline Pre-TANF wavier implemented & 0.1764 & 0.1764 & 0.1757 \\
\hline TANF implemented & 0.4153 & 0.4144 & 0.4696 \\
\hline $\mathrm{N}$ & 21,187 & 20,825 & 362 \\
\hline
\end{tabular}


SOURCE: 1992, 1993 and 1996 SIPP-SSA Panels. 
Table 4

Modified DDD Estimators (No Controls, Linear Model) for Five Outcomes

\begin{tabular}{|c|c|c|c|}
\hline & \multicolumn{3}{|c|}{ Child SSI Beneficiary } \\
\hline & Keep SSI & Lose SSI & $\begin{array}{c}\text { Difference } \\
\text { [Lose-Keep] }\end{array}$ \\
\hline \multicolumn{4}{|l|}{ Family Mother or Father Employed } \\
\hline $\begin{array}{l}\text { Unaffected group } \\
\text { Pre-PRWORA } \\
\text { PRWORA transition } \\
\text { Post-PRWORA }\end{array}$ & $\begin{array}{l}0.3952 \\
0.4653 \\
0.4558\end{array}$ & $\begin{array}{l}0.7470 \\
0.8572 \\
0.7977\end{array}$ & $\begin{array}{l}0.3518 \\
0.3919 \\
0.3419\end{array}$ \\
\hline Difference [Post-Pre] & 0.0606 & 0.0507 & -0.0099 \\
\hline $\begin{array}{l}\text { Affected group } \\
\text { Pre-PRWORA } \\
\text { PRWORA transition } \\
\text { Post-PRWORA }\end{array}$ & $\begin{array}{l}0.3952 \\
0.3389 \\
0.4874\end{array}$ & $\begin{array}{l}0.7470 \\
0.5915 \\
0.5333\end{array}$ & $\begin{array}{l}0.3518 \\
0.2526 \\
0.0459\end{array}$ \\
\hline Difference [Post-Pre] & 0.0922 & -0.2137 & -0.3059 \\
\hline Difference [Affected-Unaffected] & & & $\begin{array}{l}-0.2960 * * * \\
{[0.0802]}\end{array}$ \\
\hline \multicolumn{4}{|l|}{ Family Receives AFDC/TANF } \\
\hline $\begin{array}{l}\text { Unaffected group } \\
\text { Pre-PRWORA } \\
\text { PRWORA transition } \\
\text { Post-PRWORA }\end{array}$ & $\begin{array}{l}0.4934 \\
0.2817 \\
0.2273\end{array}$ & $\begin{array}{l}0.2350 \\
0.1072 \\
0.0674\end{array}$ & $\begin{array}{l}-0.2584 \\
-0.1745 \\
-0.1599\end{array}$ \\
\hline Difference [Post-Pre] & -0.2661 & -0.1676 & 0.0985 \\
\hline $\begin{array}{l}\text { Affected group } \\
\text { Pre-PRWORA } \\
\text { PRWORA transition } \\
\text { Post-PRWORA }\end{array}$ & $\begin{array}{l}0.4934 \\
0.3882 \\
0.2243\end{array}$ & $\begin{array}{l}0.2350 \\
0.2320 \\
0.1666\end{array}$ & $\begin{array}{l}-0.2584 \\
-0.1562 \\
-0.0577\end{array}$ \\
\hline Difference [Post-Pre] & -0.2691 & -0.0684 & 0.2007 \\
\hline Difference [Affected-Unaffected] & & & $\begin{array}{c}0.1022 * \\
{[0.0592]}\end{array}$ \\
\hline \multicolumn{4}{|l|}{ Family Receives Food Stamps } \\
\hline $\begin{array}{l}\text { Unaffected group } \\
\text { Pre-PRWORA } \\
\text { PRWORA transition } \\
\text { Post-PRWORA }\end{array}$ & $\begin{array}{l}0.6290 \\
0.3543 \\
0.3961\end{array}$ & $\begin{array}{l}0.3916 \\
0.1072 \\
0.1236\end{array}$ & $\begin{array}{l}-0.2374 \\
-0.2471 \\
-0.2725\end{array}$ \\
\hline Difference [Post-Pre] & -0.2329 & -0.2680 & -0.0351 \\
\hline $\begin{array}{l}\text { Affected group } \\
\text { Pre-PRWORA } \\
\text { PRWORA transition } \\
\text { Post-PRWORA }\end{array}$ & $\begin{array}{l}0.6290 \\
0.5141 \\
0.4086\end{array}$ & $\begin{array}{l}0.3916 \\
0.1676 \\
0.3667\end{array}$ & $\begin{array}{l}-0.2374 \\
-0.3465 \\
-0.0419\end{array}$ \\
\hline Difference [Post-Pre] & -0.2204 & -0.0249 & 0.1955 \\
\hline Difference [Affected-Unaffected] & & & $\begin{array}{c}0.2306^{* * *} \\
{[0.0779]}\end{array}$ \\
\hline
\end{tabular}


Table 4, Continued

Modified DDD Estimators (No Controls, Linear Model) for Five Outcomes

\begin{tabular}{|c|c|c|c|}
\hline & \multicolumn{3}{|c|}{ Child SSI Beneficiary } \\
\hline & Keep SSI & Lose SSI & $\begin{array}{c}\text { Difference } \\
\text { [Lose-Keep] }\end{array}$ \\
\hline \multicolumn{4}{|l|}{ Family Income-to-Poverty Ratio } \\
\hline $\begin{array}{l}\text { Unaffected group } \\
\text { Pre-PRWORA } \\
\text { PRWORA transition } \\
\text { Post-PRWORA }\end{array}$ & $\begin{array}{l}1.1535 \\
1.3181 \\
1.3822\end{array}$ & $\begin{array}{l}1.5848 \\
2.3072 \\
2.0900\end{array}$ & $\begin{array}{l}0.4313 \\
0.9891 \\
0.7078\end{array}$ \\
\hline Difference [Post-Pre] & 0.2287 & 0.5052 & 0.2765 \\
\hline $\begin{array}{l}\text { Affected group } \\
\text { Pre-PRWORA } \\
\text { PRWORA transition } \\
\text { Post-PRWORA }\end{array}$ & $\begin{array}{l}1.1535 \\
1.1568 \\
1.2025\end{array}$ & $\begin{array}{l}1.5848 \\
1.2093 \\
1.1252\end{array}$ & $\begin{array}{r}0.4313 \\
0.0525 \\
-0.0773\end{array}$ \\
\hline Difference [Post-Pre] & 0.0490 & -0.4596 & -0.5086 \\
\hline Difference [Affected-Unaffected] & & & $\begin{array}{l}-0.7851 * * * \\
{[0.1853]}\end{array}$ \\
\hline \multicolumn{4}{|l|}{ Family Income Below Poverty Threshold } \\
\hline $\begin{array}{l}\text { Unaffected group } \\
\text { Pre-PRWORA } \\
\text { PRWORA transition } \\
\text { Post-PRWORA }\end{array}$ & $\begin{array}{l}0.5220 \\
0.4157 \\
0.4280\end{array}$ & $\begin{array}{l}0.3072 \\
0.1071 \\
0.2247\end{array}$ & $\begin{array}{l}-0.2148 \\
-0.3086 \\
-0.2033\end{array}$ \\
\hline Difference [Post-Pre] & -0.0940 & -0.0825 & 0.0115 \\
\hline $\begin{array}{l}\text { Affected group } \\
\text { Pre-PRWORA } \\
\text { PRWORA transition } \\
\text { Post-PRWORA }\end{array}$ & $\begin{array}{l}0.5220 \\
0.5193 \\
0.4573\end{array}$ & $\begin{array}{l}0.3072 \\
0.3043 \\
0.4333\end{array}$ & $\begin{array}{l}-0.2148 \\
-0.2150 \\
-0.0240\end{array}$ \\
\hline Difference [Post-Pre] & -0.0647 & 0.1261 & 0.1908 \\
\hline Difference [Affected-Unaffected] & & & $\begin{array}{c}0.1793 * * \\
{[0.0834]}\end{array}$ \\
\hline
\end{tabular}

NOTES: Sample size: 21,187. Standard errors (in brackets) adjusted for repeated observations on same family using Huber correction. *** Statistically significant .01 level, ** .05 level, * .10 level (2-tailed).

SOURCE: 1992, 1993 and 1996 SIPP-SSA Panels. 
Table 5

Modified DDD Probit Models with Controls: Family Mother or Father Employed

\begin{tabular}{|c|c|c|c|}
\hline & Model 1 & Model 2 & Model 3 \\
\hline \multicolumn{4}{|l|}{ Period [1=Pre-PRWORA] } \\
\hline 2=PRWORA transition & $\begin{array}{c}0.0706^{* *} \\
{[0.0355]}\end{array}$ & $\begin{array}{l}0.1099 * * * \\
{[0.0350]}\end{array}$ & $\begin{array}{r}0.0466^{*} \\
{[0.0273]}\end{array}$ \\
\hline $3=$ Post-PRWORA & $\begin{array}{r}0.0609^{*} \\
{[0.0343]}\end{array}$ & $\begin{array}{l}0.0871 * * * \\
{[0.0326]}\end{array}$ & $\begin{array}{c}0.0258 \\
{[0.0328]}\end{array}$ \\
\hline Lose SSI & $\begin{array}{l}0.3471 * * * \\
{[0.0407]}\end{array}$ & $\begin{array}{l}0.2628 * * * \\
{[0.0586]}\end{array}$ & $\begin{array}{l}0.2742 * * * \\
{[0.0608]}\end{array}$ \\
\hline Lose SSI * Period 2 & $\begin{array}{c}0.0889 \\
{[0.1323]}\end{array}$ & $\begin{array}{l}-0.1239 \\
{[0.0763]}\end{array}$ & $\begin{array}{l}-0.1236 \\
{[0.0805]}\end{array}$ \\
\hline Lose SSI * Period 3 & $\begin{array}{c}0.0054 \\
{[0.0815]}\end{array}$ & $\begin{array}{l}-0.0464 \\
{[0.0657]}\end{array}$ & $\begin{array}{l}-0.0486 \\
{[0.0671]}\end{array}$ \\
\hline Affected $*$ Period 2 & $\begin{array}{l}-0.1234 * * \\
{[0.0483]}\end{array}$ & $\begin{array}{l}-0.0590 \\
{[0.0411]}\end{array}$ & $\begin{array}{l}-0.0585 \\
{[0.0429]}\end{array}$ \\
\hline Affected $*$ Period 3 & $\begin{array}{c}0.0313 \\
{[0.0598]}\end{array}$ & $\begin{array}{c}0.0697 \\
{[0.0609]}\end{array}$ & $\begin{array}{l}0.078 \\
{[0.0655]}\end{array}$ \\
\hline Lose SSI * Affected * Period 2 & $\begin{array}{l}-0.1483 \\
{[0.1587]}\end{array}$ & $\begin{array}{l}-0.0124 \\
{[0.1612]}\end{array}$ & $\begin{array}{l}-0.0173 \\
{[0.1615]}\end{array}$ \\
\hline Lose SSI * Affected $*$ Period 3 & $\begin{array}{l}-0.2715^{* * *} \\
{[0.0548]}\end{array}$ & $\begin{array}{l}-0.1459^{* *} \\
{[0.0479]} \\
\end{array}$ & $\begin{array}{l}-0.1563^{* *} \\
{[0.0496]}\end{array}$ \\
\hline Female [Male] & & $\begin{array}{l}-0.0353 \\
{[0.0294]}\end{array}$ & $\begin{array}{l}-0.0383 \\
{[0.0300]}\end{array}$ \\
\hline \multicolumn{4}{|c|}{ Race/ethnicity [White non-Hispanic] } \\
\hline Black non-Hispanic & & $\begin{array}{l}-0.0029 \\
{[0.0332]}\end{array}$ & $\begin{array}{l}-0.0167 \\
{[0.0337]}\end{array}$ \\
\hline Other non-Hispanic & & $\begin{array}{l}-0.0226 \\
{[0.0815]}\end{array}$ & $\begin{array}{l}-0.0310 \\
{[0.0802]}\end{array}$ \\
\hline Hispanic & & $\begin{array}{l}-0.0282 \\
{[0.0390]}\end{array}$ & $\begin{array}{l}-0.0212 \\
{[0.0401]}\end{array}$ \\
\hline \multicolumn{4}{|c|}{ Family headship [No parent present] } \\
\hline Mother only present & & $\begin{array}{c}0.9753 * * * \\
{[0.0062]}\end{array}$ & $\begin{array}{l}0.9744 * * * \\
{[0.0227]}\end{array}$ \\
\hline Father only present & & $\begin{array}{c}0.7993 * * * \\
{[0.0137]}\end{array}$ & $\begin{array}{l}0.7950 * * * \\
{[0.0402]}\end{array}$ \\
\hline Mother and father present & & $\begin{array}{l}0.9970 * * * \\
{[0.0010]}\end{array}$ & $\begin{array}{l}0.9965^{* * *} \\
{[0.0051]}\end{array}$ \\
\hline \multicolumn{4}{|c|}{ Mother education [Less than high school] } \\
\hline High school & & $\begin{array}{l}0.1758^{* * *} \\
{[0.0352]}\end{array}$ & $\begin{array}{l}0.1775^{* * *} \\
{[0.0364]}\end{array}$ \\
\hline Some college or more & & $\begin{array}{l}0.2770 * * * \\
{[0.0480]}\end{array}$ & $\begin{array}{l}0.2784 * * * \\
{[0.0481]}\end{array}$ \\
\hline \multicolumn{4}{|c|}{ Father education [Less than high school] } \\
\hline High school & & $\begin{array}{l}0.2782 * * * \\
{[0.0683]}\end{array}$ & $\begin{array}{l}0.3011^{* * *} \\
{[0.0705]}\end{array}$ \\
\hline Some college or more & & $\begin{array}{l}0.3515^{* * *} \\
{[0.0794]}\end{array}$ & $\begin{array}{c}0.3870 * * * \\
{[0.0772]}\end{array}$ \\
\hline
\end{tabular}




\section{Table 5, Continued \\ Modified DDD Probit Models with Controls: Family Mother or Father Employed}

\begin{tabular}{|c|c|c|c|}
\hline & Model 1 & Model 2 & Model 3 \\
\hline Number of adults & & $\begin{array}{l}-0.0197 \\
{[0.0172]}\end{array}$ & $\begin{array}{l}-0.0198 \\
{[0.0174]}\end{array}$ \\
\hline Number of children & & $\begin{array}{l}-0.0252 * * \\
{[0.0103]}\end{array}$ & $\begin{array}{l}-0.0242 * * \\
{[0.0103]}\end{array}$ \\
\hline State unemployment rate & & & $\begin{array}{c}0.0047 \\
{[0.0124]}\end{array}$ \\
\hline State max. AFDC/TANF benefit (/100) & & & $\begin{array}{l}-0.0353^{* * *} \\
{[0.0136]}\end{array}$ \\
\hline State max. SSI benefit $(/ 100)$ & & & $\begin{array}{c}0.0428 \\
{[0.0715]}\end{array}$ \\
\hline Pre-TANF wavier implemented & & & $\begin{array}{c}0.0105 \\
{[0.0407]}\end{array}$ \\
\hline TANF implemented & & & $\begin{array}{l}-0.0290 \\
{[0.1515]}\end{array}$ \\
\hline Year fixed effects & No & No & Yes \\
\hline Log likelihood & -14310.73 & -10805.23 & -10685.12 \\
\hline Pseudo R-squared & 0.01 & 0.25 & 0.26 \\
\hline $\mathrm{N}$ & 21,187 & 21,187 & 21,187 \\
\hline
\end{tabular}

NOTES: Marginal effects reported. Standard errors (in brackets) adjusted for repeated observations on same child using Huber correction. *** Model coefficient statistically significant .01 level, **.05 level, * .10 level (2-tailed).

SOURCE: 1992, 1993 and 1996 SIPP-SSA Panels. 
Table 6

Modified DDD Probit Models with Controls: Family Receives AFDC/TANF

\begin{tabular}{|c|c|c|c|}
\hline & Model 1 & Model 2 & Model 3 \\
\hline \multicolumn{4}{|l|}{ Period [1=Pre-PRWORA] } \\
\hline 2=PRWORA transition & $\begin{array}{l}-0.1936 * * * \\
{[0.0302]}\end{array}$ & $\begin{array}{l}-0.2026^{* * *} \\
{[0.0295]}\end{array}$ & $\begin{array}{l}-0.0340 \\
{[0.0295]}\end{array}$ \\
\hline $3=$ Post-PRWORA & $\begin{array}{l}-0.2569 * * * \\
{[0.0315]}\end{array}$ & $\begin{array}{l}-0.2771 * * * \\
{[0.0303]}\end{array}$ & $\begin{array}{l}-0.0232 \\
{[0.0354]}\end{array}$ \\
\hline Lose SSI & $\begin{array}{l}-0.2222 * * * \\
{[0.0338]}\end{array}$ & $\begin{array}{l}-0.1612 * * * \\
{[0.0362]}\end{array}$ & $\begin{array}{l}-0.1789 * * * \\
{[0.0357]}\end{array}$ \\
\hline Lose SSI * Period 2 & $\begin{array}{c}0.0159 \\
{[0.1328]}\end{array}$ & $\begin{array}{c}0.1888 \\
{[0.1466]}\end{array}$ & $\begin{array}{c}0.2298 \\
{[0.1472]}\end{array}$ \\
\hline Lose SSI * Period 3 & $\begin{array}{l}-0.0156 \\
{[0.0909]}\end{array}$ & $\begin{array}{l}-0.0167 \\
{[0.0906]}\end{array}$ & $\begin{array}{l}-0.0085 \\
{[0.0925]}\end{array}$ \\
\hline Affected $*$ Period 2 & $\begin{array}{c}0.1144^{* *} \\
{[0.0535]}\end{array}$ & $\begin{array}{c}0.0617 \\
{[0.0574]}\end{array}$ & $\begin{array}{c}0.0583 \\
{[0.0584]}\end{array}$ \\
\hline Affected $*$ Period 3 & $\begin{array}{l}-0.0037 \\
{[0.0627]}\end{array}$ & $\begin{array}{l}-0.0355 \\
{[0.0584]}\end{array}$ & $\begin{array}{l}-0.0569 \\
{[0.0580]}\end{array}$ \\
\hline Lose SSI * Affected * Period 2 & $\begin{array}{c}0.1844 \\
{[0.1655]} \\
\end{array}$ & $\begin{array}{c}0.1346 \\
{[0.1752]} \\
\end{array}$ & $\begin{array}{c}0.0849 \\
{[0.1675]} \\
\end{array}$ \\
\hline Lose SSI * Affected * Period 3 & $\begin{array}{r}0.2115^{*} \\
{[0.1084]}\end{array}$ & $\begin{array}{r}0.1858^{*} \\
{[0.1153]} \\
\end{array}$ & $\begin{array}{c}0.1850 \\
{[0.1178]}\end{array}$ \\
\hline Female [Male] & & $\begin{array}{c}0.0028 \\
{[0.0364]}\end{array}$ & $\begin{array}{c}0.0175 \\
{[0.0367]}\end{array}$ \\
\hline \multicolumn{4}{|c|}{ Race/ethnicity [White non-Hispanic] } \\
\hline Black non-Hispanic & & $\begin{array}{l}0.1261 * * * \\
{[0.0414]}\end{array}$ & $\begin{array}{l}0.1583^{* * *} \\
{[0.0420]}\end{array}$ \\
\hline Other non-Hispanic & & $\begin{array}{c}0.1367 \\
{[0.1175]}\end{array}$ & $\begin{array}{c}0.1532 \\
{[0.1212]}\end{array}$ \\
\hline Hispanic & & $\begin{array}{c}0.1234^{* *} \\
{[0.0529]}\end{array}$ & $\begin{array}{r}0.0887^{*} \\
{[0.0547]}\end{array}$ \\
\hline \multicolumn{4}{|c|}{ Family headship [No parent present] } \\
\hline Mother only present & & $\begin{array}{l}0.2473 * * * \\
{[0.0617]}\end{array}$ & $\begin{array}{l}0.2112^{* * *} \\
{[0.0624]}\end{array}$ \\
\hline Father only present & & $\begin{array}{c}0.0299 \\
{[0.1302]}\end{array}$ & $\begin{array}{l}-0.0167 \\
{[0.1237]}\end{array}$ \\
\hline Mother and father present & & $\begin{array}{c}0.0472 \\
{[0.0782]}\end{array}$ & $\begin{array}{c}0.0171 \\
{[0.0767]}\end{array}$ \\
\hline \multicolumn{4}{|c|}{ Mother education [Less than high school] } \\
\hline High school & & $\begin{array}{l}-0.0603 \\
{[0.0387]}\end{array}$ & $\begin{array}{l}-0.0606 \\
{[0.0388]}\end{array}$ \\
\hline Some college or more & & $\begin{array}{l}-0.1555^{* * *} \\
{[0.0443]}\end{array}$ & $\begin{array}{l}-0.1633^{* * *} \\
{[0.0416]}\end{array}$ \\
\hline \multicolumn{4}{|c|}{ Father education [Less than high school] } \\
\hline High school & & $\begin{array}{l}-0.1096 \\
{[0.0652]}\end{array}$ & $\begin{array}{l}-0.1475^{* *} \\
{[0.0593]}\end{array}$ \\
\hline Some college or more & & $\begin{array}{l}-0.0663 \\
{[0.0756]}\end{array}$ & $\begin{array}{l}-0.1344 * \\
{[0.0662]}\end{array}$ \\
\hline
\end{tabular}




\section{Table 6, Continued}

Modified DDD Probit Models with Controls: Family Receives AFDC/TANF

\begin{tabular}{|c|c|c|c|}
\hline & Model 1 & Model 2 & Model 3 \\
\hline Number of adults & & $\begin{array}{l}-0.0521^{* *} \\
{[0.0236]}\end{array}$ & $\begin{array}{l}-0.0490^{* *} \\
{[0.0228]}\end{array}$ \\
\hline Number of children & & $\begin{array}{c}0.0691 * * * \\
{[0.0125]}\end{array}$ & $\begin{array}{l}0.0687 * * * \\
{[0.0126]}\end{array}$ \\
\hline State unemployment rate & & & $\begin{array}{l}-0.0233 \\
{[0.0155]}\end{array}$ \\
\hline State max. AFDC/TANF benefit (/100) & & & $\begin{array}{l}0.0809^{* * *} \\
{[0.0149]}\end{array}$ \\
\hline State max. SSI benefit $(/ 100)$ & & & $\begin{array}{c}0.0350 \\
{[0.0749]}\end{array}$ \\
\hline Pre-TANF wavier implemented & & & $\begin{array}{c}0.0189 \\
{[0.0485]}\end{array}$ \\
\hline TANF implemented & & & $\begin{array}{l}-0.3642 * * \\
{[0.1617]}\end{array}$ \\
\hline Year fixed effects & No & No & Yes \\
\hline Log likelihood & -13322.05 & -11366.15 & -10555.83 \\
\hline Pseudo R-squared & 0.05 & 0.19 & 0.25 \\
\hline $\mathrm{N}$ & 21,187 & 21,187 & 21,187 \\
\hline
\end{tabular}

NOTES: Marginal effects reported. Standard errors (in brackets) adjusted for repeated observations on same child using Huber correction. *** Model coefficient statistically significant .01 level, ** .05 level, * .10 level (2-tailed).

SOURCE: 1992, 1993 and 1996 SIPP-SSA Panels. 
Table 7

Modified DDD Probit Models with Controls: Family Receives Food Stamps

\begin{tabular}{|c|c|c|c|}
\hline & Model 1 & Model 2 & Model 3 \\
\hline \multicolumn{4}{|l|}{ Period [1=Pre-PRWORA] } \\
\hline 2=PRWORA transition & $\begin{array}{l}-0.2699 * * * \\
{[0.0335]}\end{array}$ & $\begin{array}{l}-0.2690^{* * *} \\
{[0.0350]}\end{array}$ & $\begin{array}{l}-0.0498 \\
{[0.0309]}\end{array}$ \\
\hline $3=$ Post-PRWORA & $\begin{array}{l}-0.2325^{* * *} \\
{[0.0339]}\end{array}$ & $\begin{array}{l}-0.2274 * * * \\
{[0.0348]}\end{array}$ & $\begin{array}{c}0.0035 \\
{[0.0353]}\end{array}$ \\
\hline Lose SSI & $\begin{array}{l}-0.2305^{* * *} \\
{[0.0463]}\end{array}$ & $\begin{array}{l}-0.1878^{* * *} \\
{[0.0471]}\end{array}$ & $\begin{array}{l}-0.2009^{* * *} \\
{[0.0482]}\end{array}$ \\
\hline Lose SSI * Period 2 & $\begin{array}{l}-0.1045 \\
{[0.1348]}\end{array}$ & $\begin{array}{l}-0.0095 \\
{[0.1433]}\end{array}$ & $\begin{array}{c}0.0034 \\
{[0.1439]}\end{array}$ \\
\hline Lose SSI * Period 3 & $\begin{array}{l}-0.1145 \\
{[0.0855]}\end{array}$ & $\begin{array}{l}-0.0892 \\
{[0.0905]}\end{array}$ & $\begin{array}{l}-0.0783 \\
{[0.0935]}\end{array}$ \\
\hline Affected $*$ Period 2 & $\begin{array}{l}0.1581 * * * \\
{[0.0500]}\end{array}$ & $\begin{array}{c}0.1162 * * \\
{[0.0556]}\end{array}$ & $\begin{array}{c}0.1163^{* *} \\
{[0.0563]}\end{array}$ \\
\hline Affected $*$ Period 3 & $\begin{array}{c}0.0129 \\
{[0.0560]}\end{array}$ & $\begin{array}{l}-0.0238 \\
{[0.0560]}\end{array}$ & $\begin{array}{l}-0.0240 \\
{[0.0574]}\end{array}$ \\
\hline Lose SSI * Affected $*$ Period 2 & $\begin{array}{l}-0.0678 \\
{[0.1878]}\end{array}$ & $\begin{array}{l}-0.1101 \\
{[0.1914]}\end{array}$ & $\begin{array}{l}-0.1174 \\
{[0.1917]}\end{array}$ \\
\hline Lose SSI * Affected * Period 3 & $\begin{array}{l}0.2790^{* * *} \\
{[0.0712]}\end{array}$ & $\begin{array}{l}0.2512 * * * \\
{[0.0792]}\end{array}$ & $\begin{array}{l}0.2607 * * * \\
{[0.0773]}\end{array}$ \\
\hline Female [Male] & & $\begin{array}{l}-0.0178 \\
{[0.0367]}\end{array}$ & $\begin{array}{l}-0.0044 \\
{[0.0368]}\end{array}$ \\
\hline \multicolumn{4}{|c|}{ Race/ethnicity [White non-Hispanic] } \\
\hline Black non-Hispanic & & $\begin{array}{l}0.1059 * * * \\
{[0.0407]}\end{array}$ & $\begin{array}{l}0.1098^{* * *} \\
{[0.0413]}\end{array}$ \\
\hline Other non-Hispanic & & $\begin{array}{c}0.1645^{*} \\
{[0.0859]}\end{array}$ & $\begin{array}{r}0.1738^{*} \\
{[0.0854]}\end{array}$ \\
\hline Hispanic & & $\begin{array}{r}0.0973 * \\
{[0.0514]}\end{array}$ & $\begin{array}{c}0.0758 \\
{[0.0528]}\end{array}$ \\
\hline \multicolumn{4}{|c|}{ Family headship [No parent present] } \\
\hline Mother only present & & $\begin{array}{l}0.3714 * * * \\
{[0.0606]}\end{array}$ & $\begin{array}{l}0.3692 * * * \\
{[0.0616]}\end{array}$ \\
\hline Father only present & & $\begin{array}{c}0.0735 \\
{[0.1209]}\end{array}$ & $\begin{array}{c}0.0702 \\
{[0.1209]}\end{array}$ \\
\hline Mother and father present & & $\begin{array}{l}0.2842 * * * \\
{[0.0699]}\end{array}$ & $\begin{array}{l}0.2722 * * * \\
{[0.0720]}\end{array}$ \\
\hline \multicolumn{4}{|c|}{ Mother education [Less than high school] } \\
\hline High school & & $\begin{array}{l}-0.0925^{* *} \\
{[0.0402]}\end{array}$ & $\begin{array}{l}-0.0977 * * \\
{[0.0404]}\end{array}$ \\
\hline Some college or more & & $\begin{array}{l}-0.1948 * * * \\
{[0.0476]}\end{array}$ & $\begin{array}{l}-0.1987 * * * \\
{[0.0477]}\end{array}$ \\
\hline \multicolumn{4}{|c|}{ Father education [Less than high school] } \\
\hline High school & & $\begin{array}{l}-0.0014 \\
{[0.0642]}\end{array}$ & $\begin{array}{l}-0.0136 \\
{[0.0647]}\end{array}$ \\
\hline Some college or more & & -0.1214 & $-0.1306^{*}$ \\
\hline
\end{tabular}


Table 7, Continued

Modified DDD Probit Models with Controls: Family Receives Food Stamps

\begin{tabular}{|c|c|c|c|}
\hline & Model 1 & Model 2 & Model 3 \\
\hline Number of adults & & $\begin{array}{l}-0.0649 * * * \\
{[0.0220]}\end{array}$ & $\begin{array}{l}-0.0596^{* * *} \\
{[0.0218]}\end{array}$ \\
\hline Number of children & & $\begin{array}{l}0.0673 * * * \\
{[0.0131]}\end{array}$ & $\begin{array}{c}0.0691 * * * \\
{[0.0131]}\end{array}$ \\
\hline State unemployment rate & & & $\begin{array}{c}0.0299 * \\
{[0.0170]}\end{array}$ \\
\hline State max. AFDC/TANF benefit (/100) & & & $\begin{array}{c}0.0185 \\
{[0.0146]}\end{array}$ \\
\hline State max. SSI benefit $(/ 100)$ & & & $\begin{array}{l}-0.0747 \\
{[0.0797]}\end{array}$ \\
\hline Pre-TANF wavier implemented & & & $\begin{array}{l}-0.0250 \\
{[0.0488]}\end{array}$ \\
\hline TANF implemented & & & $\begin{array}{l}-0.1462 \\
{[0.1672]}\end{array}$ \\
\hline Year fixed effects & No & No & Yes \\
\hline Log likelihood & -14036.09 & -12457.91 & -12172.17 \\
\hline Pseudo R-squared & 0.04 & 0.15 & 0.17 \\
\hline $\mathrm{N}$ & 21,187 & 21,187 & 21,187 \\
\hline
\end{tabular}

NOTES: Marginal effects reported. Standard errors (in brackets) adjusted for repeated observations on same child using Huber correction. *** Model coefficient statistically significant .01 level, ** .05 level, * .10 level (2-tailed). SOURCE: 1992, 1993 and 1996 SIPP-SSA Panels. 
Table 8

Modified DDD OLS Models with Controls: Family Income-to-Poverty Ratio

\begin{tabular}{|c|c|c|c|}
\hline & Model 1 & Model 2 & Model 3 \\
\hline \multicolumn{4}{|l|}{ Period [1=Pre-PRWORA] } \\
\hline 2=PRWORA transition & $\begin{array}{l}0.1646 * * * \\
{[0.0626]}\end{array}$ & $\begin{array}{c}0.0973^{*} \\
{[0.0568]}\end{array}$ & $\begin{array}{l}-0.0024 \\
{[0.0433]}\end{array}$ \\
\hline $3=$ Post-PRWORA & $\begin{array}{l}0.2287 * * * \\
{[0.0691]}\end{array}$ & $\begin{array}{c}0.1613 * * \\
{[0.0634]}\end{array}$ & $\begin{array}{c}0.1783 * * \\
{[0.0903]}\end{array}$ \\
\hline Lose SSI & $\begin{array}{l}0.4313 * * * \\
{[0.0894]}\end{array}$ & $\begin{array}{l}0.2173 * * * \\
{[0.0774]}\end{array}$ & $\begin{array}{l}0.2195^{* * *} \\
{[0.0759]}\end{array}$ \\
\hline Lose SSI * Period 2 & $\begin{array}{c}0.5578 * * \\
{[0.2438]}\end{array}$ & $\begin{array}{c}0.2958 \\
{[0.2200]}\end{array}$ & $\begin{array}{c}0.2887 \\
{[0.2240]}\end{array}$ \\
\hline Lose SSI * Period 3 & $\begin{array}{c}0.2765 \\
{[0.1773]}\end{array}$ & $\begin{array}{c}0.1329 \\
{[0.1516]}\end{array}$ & $\begin{array}{c}0.1362 \\
{[0.1500]}\end{array}$ \\
\hline Affected $*$ Period 2 & $\begin{array}{l}-0.1613^{*} \\
{[0.0851]}\end{array}$ & $\begin{array}{l}-0.0259 \\
{[0.0781]}\end{array}$ & $\begin{array}{l}-0.0235 \\
{[0.0787]}\end{array}$ \\
\hline Affected $*$ Period 3 & $\begin{array}{l}-0.1797^{*} \\
{[0.0971]}\end{array}$ & $\begin{array}{l}-0.1054 \\
{[0.0849]}\end{array}$ & $\begin{array}{l}-0.1147 \\
{[0.0870]}\end{array}$ \\
\hline Lose SSI * Affected * Period 2 & $\begin{array}{l}-0.3788 \\
{[0.4014]}\end{array}$ & $\begin{array}{l}-0.1595 \\
{[0.3397]} \\
\end{array}$ & $\begin{array}{l}-0.1642 \\
{[0.3407]}\end{array}$ \\
\hline Lose SSI * Affected $*$ Period 3 & $\begin{array}{l}-0.7851 * * * \\
{[0.1853]}\end{array}$ & $\begin{array}{l}-0.4865^{* * *} \\
{[0.1665]}\end{array}$ & $\begin{array}{l}-0.5264 * * * \\
{[0.1655]}\end{array}$ \\
\hline Female [Male] & & $\begin{array}{c}0.0364 \\
{[0.0564]}\end{array}$ & $\begin{array}{c}0.0314 \\
{[0.0555]}\end{array}$ \\
\hline \multicolumn{4}{|c|}{ Race/ethnicity [White non-Hispanic] } \\
\hline Black non-Hispanic & & $\begin{array}{l}-0.1408^{* *} \\
{[0.0693]}\end{array}$ & $\begin{array}{l}-0.1261^{*} \\
{[0.0665]}\end{array}$ \\
\hline Other non-Hispanic & & $\begin{array}{l}-0.0258 \\
{[0.1116]}\end{array}$ & $\begin{array}{l}-0.0469 \\
{[0.1124]}\end{array}$ \\
\hline Hispanic & & $\begin{array}{l}-0.1716^{* * * *} \\
{[0.0645]}\end{array}$ & $\begin{array}{l}-0.1811 * * * \\
{[0.0654]}\end{array}$ \\
\hline \multicolumn{4}{|c|}{ Family headship [No parent present] } \\
\hline Mother only present & & $\begin{array}{l}-0.1002 \\
{[0.1839]}\end{array}$ & $\begin{array}{l}-0.1249 \\
{[0.1909]}\end{array}$ \\
\hline Father only present & & $\begin{array}{c}0.1477 \\
{[0.3280]}\end{array}$ & $\begin{array}{c}0.1405 \\
{[0.3229]}\end{array}$ \\
\hline Mother and father present & & $\begin{array}{l}-0.0961 \\
{[0.1791]}\end{array}$ & $\begin{array}{l}-0.0926 \\
{[0.1789]}\end{array}$ \\
\hline \multicolumn{4}{|c|}{ Mother education [Less than high school] } \\
\hline High school & & $\begin{array}{l}0.1547^{* * *} \\
{[0.0466]}\end{array}$ & $\begin{array}{l}0.1579 * * * \\
{[0.0460]}\end{array}$ \\
\hline Some college or more & & $\begin{array}{l}0.3606^{* * * *} \\
{[0.0641]}\end{array}$ & $\begin{array}{l}0.3689^{* * *} \\
{[0.0650]}\end{array}$ \\
\hline \multicolumn{4}{|c|}{ Father education [Less than high school] } \\
\hline High school & & $\begin{array}{c}0.1768^{* *} \\
{[0.0830]}\end{array}$ & $\begin{array}{c}0.1656^{* *} \\
{[0.0833]}\end{array}$ \\
\hline Some college or more & & $\begin{array}{c}0.5913 * * * \\
{[0.1159]}\end{array}$ & $\begin{array}{c}0.5605^{* * *} \\
{[0.1156]}\end{array}$ \\
\hline
\end{tabular}


Table 8, Continued

Modified DDD OLS Models with Controls: Family Income-to-Poverty Ratio

\begin{tabular}{|c|c|c|c|}
\hline & Model 1 & Model 2 & Model 3 \\
\hline Number of adults & & $\begin{array}{c}0.1529 * * * \\
{[0.0465]}\end{array}$ & $\begin{array}{l}0.1463 * * * \\
{[0.0476]}\end{array}$ \\
\hline Number of children & & $\begin{array}{l}-0.1146 * * * \\
{[0.0178]}\end{array}$ & $\begin{array}{l}-0.1174 * * * \\
{[0.0177]}\end{array}$ \\
\hline State unemployment rate & & & $\begin{array}{c}0.0017 \\
{[0.0284]}\end{array}$ \\
\hline State max. AFDC/TANF benefit $(/ 100)$ & & & $\begin{array}{r}0.0398^{*} \\
{[0.0214]}\end{array}$ \\
\hline State max. SSI benefit $(/ 100)$ & & & $\begin{array}{l}-0.0407 \\
{[0.1285]}\end{array}$ \\
\hline Pre-TANF wavier implemented & & & $\begin{array}{c}0.0609 \\
{[0.0630]}\end{array}$ \\
\hline TANF implemented & & & $\begin{array}{c}0.2524 \\
{[0.2182]}\end{array}$ \\
\hline Year fixed effects & No & No & Yes \\
\hline R-squared & 0.02 & 0.16 & 0.17 \\
\hline $\mathrm{N}$ & 21,187 & 21,187 & 21,187 \\
\hline
\end{tabular}

NOTES: Marginal effects reported. Standard errors (in brackets) adjusted for repeated observations on same child using Huber correction. *** Model coefficient statistically significant .01 level, ** .05 level, * .10 level (2-tailed). SOURCE: 1992, 1993 and 1996 SIPP-SSA Panels. 
Table 9

Modified DDD Probit Models with Controls: Family Income Below Poverty Threshold

\begin{tabular}{|c|c|c|c|}
\hline & Model 1 & Model 2 & Model 3 \\
\hline \multicolumn{4}{|l|}{ Period [1=Pre-PRWORA] } \\
\hline 2=PRWORA transition & $\begin{array}{l}-0.1055^{* * *} \\
{[0.0318]}\end{array}$ & $\begin{array}{l}-0.0844 * * * \\
{[0.0325]}\end{array}$ & $\begin{array}{l}-0.0249 \\
{[0.0318]}\end{array}$ \\
\hline $3=$ Post-PRWORA & $\begin{array}{l}-0.0937 * * * \\
{[0.0300]}\end{array}$ & $\begin{array}{l}-0.0693 * * \\
{[0.0301]}\end{array}$ & $\begin{array}{l}-0.0694 * \\
{[0.0381]}\end{array}$ \\
\hline Lose SSI & $\begin{array}{l}-0.2093 * * * \\
{[0.0411]}\end{array}$ & $\begin{array}{l}-0.1268 * * * \\
{[0.0458]}\end{array}$ & $\begin{array}{l}-0.1289^{* * *} \\
{[0.0450]}\end{array}$ \\
\hline Lose SSI * Period 2 & $\begin{array}{l}-0.1785 \\
{[0.1208]}\end{array}$ & $\begin{array}{l}-0.0803 \\
{[0.1306]}\end{array}$ & $\begin{array}{l}-0.0779 \\
{[0.1317]}\end{array}$ \\
\hline Lose SSI * Period 3 & $\begin{array}{l}-0.0064 \\
{[0.0758]}\end{array}$ & $\begin{array}{c}0.0446 \\
{[0.0727]}\end{array}$ & $\begin{array}{c}0.0419 \\
{[0.0728]}\end{array}$ \\
\hline Affected $*$ Period 2 & $\begin{array}{c}0.1038^{* *} \\
{[0.0467]}\end{array}$ & $\begin{array}{c}0.0386 \\
{[0.0491]}\end{array}$ & $\begin{array}{c}0.0343 \\
{[0.0489]}\end{array}$ \\
\hline Affected $*$ Period 3 & $\begin{array}{c}0.0296 \\
{[0.0532]}\end{array}$ & $\begin{array}{l}-0.0036 \\
{[0.0519]}\end{array}$ & $\begin{array}{c}0.0001 \\
{[0.0521]}\end{array}$ \\
\hline Lose SSI * Affected * Period 2 & $\begin{array}{c}0.0700 \\
{[0.1825]}\end{array}$ & $\begin{array}{c}0.0097 \\
{[0.1866]}\end{array}$ & $\begin{array}{c}0.0094 \\
{[0.1901]}\end{array}$ \\
\hline Lose SSI * Affected * Period 3 & $\begin{array}{c}0.1988^{* *} \\
{[0.0830]}\end{array}$ & $\begin{array}{c}0.0852 \\
{[0.0916]}\end{array}$ & $\begin{array}{c}0.1112 \\
{[0.0899]}\end{array}$ \\
\hline Female [Male] & & $\begin{array}{l}-0.0234 \\
{[0.0294]}\end{array}$ & $\begin{array}{l}-0.0200 \\
{[0.0293]}\end{array}$ \\
\hline \multicolumn{4}{|c|}{ Race/ethnicity [White non-Hispanic] } \\
\hline Black non-Hispanic & & $\begin{array}{c}0.0723^{* *} \\
{[0.0324]}\end{array}$ & $\begin{array}{l}0.0710^{* *} \\
{[0.0330]}\end{array}$ \\
\hline Other non-Hispanic & & $\begin{array}{c}0.0775 \\
{[0.0741]}\end{array}$ & $\begin{array}{c}0.0869 \\
{[0.0736]}\end{array}$ \\
\hline Hispanic & & $\begin{array}{l}0.1180 * * * \\
{[0.0401]}\end{array}$ & $\begin{array}{l}0.1240 * * * \\
{[0.0406]}\end{array}$ \\
\hline \multicolumn{4}{|c|}{ Family headship [No parent present] } \\
\hline Mother only present & & $\begin{array}{c}0.0206 \\
{[0.0534]}\end{array}$ & $\begin{array}{c}0.0279 \\
{[0.0534]}\end{array}$ \\
\hline Father only present & & $\begin{array}{l}-0.0166 \\
{[0.0969]}\end{array}$ & $\begin{array}{l}-0.0114 \\
{[0.0973]}\end{array}$ \\
\hline Mother and father present & & $\begin{array}{l}-0.0207 \\
{[0.0611]}\end{array}$ & $\begin{array}{l}-0.0202 \\
{[0.0613]}\end{array}$ \\
\hline \multicolumn{4}{|c|}{ Mother education [Less than high school] } \\
\hline High school & & $\begin{array}{l}-0.1203 * * * \\
{[0.0327]}\end{array}$ & $\begin{array}{l}-0.1215^{* * *} \\
{[0.0326]}\end{array}$ \\
\hline Some college or more & & $\begin{array}{l}-0.2119^{* * *} \\
{[0.0355]}\end{array}$ & $\begin{array}{l}-0.2149^{* * *} \\
{[0.0357]}\end{array}$ \\
\hline \multicolumn{4}{|c|}{ Father education [Less than high school] } \\
\hline High school & & $\begin{array}{l}-0.1013^{* *} \\
{[0.0505]}\end{array}$ & $\begin{array}{l}-0.1051^{* *} \\
{[0.0509]}\end{array}$ \\
\hline Some college or more & & $\begin{array}{l}-0.2098 * * * \\
{[0.0535]}\end{array}$ & $\begin{array}{l}-0.2016^{* * *} \\
{[0.0542]}\end{array}$ \\
\hline
\end{tabular}


Table 9, Continued

Modified DDD Probit Models with Controls: Family Income Below Poverty Threshold

\begin{tabular}{|c|c|c|c|}
\hline & Model 1 & Model 2 & Model 3 \\
\hline Number of adults & & $\begin{array}{l}-0.1009 * * * \\
{[0.0199]}\end{array}$ & $\begin{array}{l}-0.0980^{* * *} \\
{[0.0202]}\end{array}$ \\
\hline Number of children & & $\begin{array}{l}0.0638 * * * \\
{[0.0108]}\end{array}$ & $\begin{array}{l}0.0661 * * * \\
{[0.0106]}\end{array}$ \\
\hline State unemployment rate & & & $\begin{array}{l}-0.0021 \\
{[0.0131]}\end{array}$ \\
\hline State max. AFDC/TANF benefit $(/ 100)$ & & & $\begin{array}{l}-0.0085 \\
{[0.0109]}\end{array}$ \\
\hline State max. SSI benefit $(/ 100)$ & & & $\begin{array}{l}-0.0278 \\
{[0.0606]}\end{array}$ \\
\hline Pre-TANF wavier implemented & & & $\begin{array}{l}-0.0637 \\
{[0.0414]}\end{array}$ \\
\hline TANF implemented & & & $\begin{array}{l}-0.1340 \\
{[0.1420]}\end{array}$ \\
\hline Year fixed effects & No & No & Yes \\
\hline Log likelihood & -14543.43 & -12944.99 & -12867.35 \\
\hline Pseudo R-squared & 0.01 & 0.12 & 0.12 \\
\hline $\mathrm{N}$ & 21,187 & 21,187 & 21,187 \\
\hline
\end{tabular}

NOTES: Marginal effects reported. Standard errors (in brackets) adjusted for repeated observations on same child using Huber correction. *** Model coefficient statistically significant .01 level, ** .05 level, * .10 level (2-tailed).

SOURCE: 1992, 1993 and 1996 SIPP-SSA Panels. 
Table 10

Alternative Model Specifications for Five Outcomes

\begin{tabular}{|c|c|c|c|c|c|}
\hline \multirow{3}{*}{ Outcome } & \multicolumn{5}{|c|}{ Specification } \\
\hline & $\begin{array}{l}\text { Preferred } \\
\text { DDD }\end{array}$ & $\begin{array}{l}\text { Alternative } \\
\text { DDD }\end{array}$ & $\begin{array}{l}\text { Alternative } \\
\text { DDD }\end{array}$ & $\begin{array}{l}\text { Alternative } \\
\text { DDD }\end{array}$ & $\begin{array}{c}\text { Alternative } \\
\text { DD }\end{array}$ \\
\hline & $\begin{array}{l}\text { 1-month } \\
\text { window }\end{array}$ & $\begin{array}{l}\text { 4-month } \\
\text { window }\end{array}$ & $\begin{array}{l}\text { 6-month } \\
\text { window }\end{array}$ & $\begin{array}{l}\text { 12-month } \\
\text { window }\end{array}$ & $\begin{array}{l}\text { 1-month } \\
\text { window }\end{array}$ \\
\hline Family mother or father employed & $\begin{array}{l}-0.1563 * * \\
{[0.0496]}\end{array}$ & $\begin{array}{l}-0.2261^{* *} \\
{[0.0556]}\end{array}$ & $\begin{array}{l}-0.0717 \\
{[0.1532]}\end{array}$ & $\begin{array}{l}-0.1392 * \\
{[0.0445]}\end{array}$ & $\begin{array}{l}-0.1125^{* *} \\
{[0.0463]}\end{array}$ \\
\hline Family receives AFDC/TANF & $\begin{array}{c}0.1850 \\
{[0.1178]}\end{array}$ & $\begin{array}{c}0.1181 \\
{[0.2021]}\end{array}$ & $\begin{array}{c}0.1255 \\
{[0.2443]}\end{array}$ & $\begin{array}{c}0.0918 \\
{[0.2498]}\end{array}$ & $\begin{array}{c}0.0734 \\
{[0.0813]}\end{array}$ \\
\hline Family receives food stamps & $\begin{array}{l}0.2607^{* * *} \\
{[0.0773]}\end{array}$ & $\begin{array}{c}0.2381 \\
{[0.1317]}\end{array}$ & $\begin{array}{r}0.2502 * \\
{[0.1513]}\end{array}$ & $\begin{array}{c}0.3209 \\
{[0.1571]}\end{array}$ & $\begin{array}{c}0.0623 \\
{[0.0729]}\end{array}$ \\
\hline Family income-to-poverty ratio & $\begin{array}{l}-0.5264 * * * \\
{[0.1655]}\end{array}$ & $\begin{array}{l}-0.2707 \\
{[0.2618]}\end{array}$ & $\begin{array}{l}-0.0465 \\
{[0.2395]}\end{array}$ & $\begin{array}{c}0.1823 \\
{[0.2831]}\end{array}$ & $\begin{array}{l}-0.0961 \\
{[0.1197]}\end{array}$ \\
\hline Family income below poverty threshold & $\begin{array}{c}0.1112 \\
{[0.0899]}\end{array}$ & $\begin{array}{c}0.1491 \\
{[0.1638]}\end{array}$ & $\begin{array}{c}0.2423 \\
{[0.2093]}\end{array}$ & $\begin{array}{l}-0.0311 \\
{[0.2296]}\end{array}$ & $\begin{array}{c}0.0953 \\
{[0.0645]}\end{array}$ \\
\hline $\mathrm{N}$ & 21,187 & 17,774 & 16,234 & 12,048 & 21,187 \\
\hline
\end{tabular}

NOTES: Marginal effects for two-way (DD) or three-way (DDD) interaction terms from probit models, except family income-topoverty ratio effects which are OLS coefficients. Effects in first column are the same as those in Model 3 in Tables 5 to 9 . All other models have same set of controls as Model 3. Standard errors (in brackets) adjusted for repeated observations on same child using Huber correction. *** Model coefficient statistically significant .01 level, ** .05 level, * .10 level (2-tailed).

SOURCE: 1992, 1993 and 1996 SIPP-SSA Panels. 